\title{
Integrating peatlands into the coupled Canadian Land Surface Scheme (CLASS) v3.6 and the Canadian Terrestrial Ecosystem Model (CTEM) v2.0
}

\author{
Yuanqiao Wu ${ }^{1}$, Diana L. Verseghy ${ }^{1}$, and Joe R. Melton ${ }^{2}$ \\ ${ }^{1}$ Climate Processes Section, Climate Research Division, Environment and Climate Change Canada, 4905 Dufferin Street, \\ Toronto, ON, M3H 5T4, Canada \\ ${ }^{2}$ Climate Processes Section, Climate Research Division, Environment and Climate Change Canada, University of Victoria, \\ 3800 Finnerty Road, Victoria, BC, V8P 5C2, Canada
}

Correspondence to: Joe Melton (joe.melton@ canada.ca)

Received: 22 October 2015 - Published in Geosci. Model Dev. Discuss.: 27 November 2015

Revised: 9 May 2016 - Accepted: 24 June 2016 - Published: 11 August 2016

\begin{abstract}
Peatlands, which contain large carbon stocks that must be accounted for in the global carbon budget, are poorly represented in many earth system models. We integrated peatlands into the coupled Canadian Land Surface Scheme (CLASS) and the Canadian Terrestrial Ecosystem Model (CTEM), which together simulate the fluxes of water, energy, and $\mathrm{CO}_{2}$ at the land surface-atmosphere boundary in the family of Canadian Earth system models (CanESMs). New components and algorithms were added to represent the unique features of peatlands, such as their characteristic ground floor vegetation (mosses), the slow decomposition of carbon in the water-logged soils and the interaction between the water, energy, and carbon cycles. This paper presents the modifications introduced into the CLASS-CTEM modelling framework together with site-level evaluations of the model performance for simulated water, energy and carbon fluxes at eight different peatland sites. The simulated daily gross primary production (GPP) and ecosystem respiration are well correlated with observations, with values of the Pearson correlation coefficient higher than 0.8 and 0.75 respectively. The simulated mean annual net ecosystem production at the eight test sites is $87 \mathrm{~g} \mathrm{C} \mathrm{m}^{-2} \mathrm{yr}^{-1}$, which is $22 \mathrm{~g} \mathrm{C} \mathrm{m}^{-2} \mathrm{yr}^{-1}$ higher than the observed annual mean. The general peatland model compares well with other site-level and regional-level models for peatlands, and is able to represent bogs and fens under a range of climatic and geographical conditions.
\end{abstract}

\section{Introduction}

Peatlands represent about $20 \%$ of the global soil carbon (C) pool and have played a critical role in regulating the global climate since the onset of the Holocene (Yu et al., 2013). Peatlands have accumulated more than $600 \mathrm{GtC}$ over the Holocene and serve as a long-term $\mathrm{C}$ sink at a rate higher than $5 \mathrm{Gt} C$ per century on average (Yu et al., 2010). Over $90 \%$ of the world's peatlands are located in the Northern Hemisphere (Yu et al., 2010) in large areas such as the Hudson Bay lowlands, the west Siberian lowlands, and the FennoSoviet lowlands, where gross primary production (GPP) is comparatively low (e.g. Yebra et al., 2015). The inhibited decomposition in waterlogged organic soil persistently sequesters $\mathrm{C}$ in peatlands, despite the relatively low primary production.

Peatlands are usually characterized by a ground layer of bryophytes or sedges covering $80-100 \%$ of the surface (Vitt, 2014). Bryophytes, especially Sphagnum mosses, are non-vascular land plants that are able to effectively capture and store water and nutrients (Turetsky, 2003). Globally, bryophytes and lichens are widely present, especially over tundra, boreal forest floor and desert, and are estimated to account for a net $\mathrm{C}$ uptake of $0.34 \mathrm{Gt} \mathrm{C} \mathrm{yr}^{-1}$ on average (Porada et al., 2013), out of $5.0( \pm 0.9) \mathrm{Gt} \mathrm{C} \mathrm{yr}^{-1}$ global net $\mathrm{C}$ uptake by land and oceans between 1960 and 2010 (Ballantyne et al., 2012). Peatlands can be classified as either fens or bogs. Bogs are dependent upon precipitation for water and nutrients while fens receive additional contributions from ground 
and surface waters (Rydin and Jeglum, 2006). The different sources of nutrients between bogs and fens leads to differences in their physical state including hydrology, soil and water chemistry, vegetation, and nutrient availability. These differences can lead to differences in the fluxes of carbon from these fens vs. bogs, e.g. fen methane emissions are more sensitive to vegetation type but less sensitive to temperature than bogs (Turetsky et al., 2014). Fens generally produce the most methane with water tables at or above the peat surface, while bogs produce the most methane with the water table below the peat surface (Turetsky et al., 2014).

Peatlands are particularly vulnerable to $\mathrm{C}$ loss under climate change. The IPCC Fifth Assessment Report (AR5) projected a large increase of temperature and a risk of lower soil moisture (Christensen et al., 2013; Seneviratne et al., 2010 ) in the boreal region. Warmer temperatures and drought can both stimulate the decomposition of peat and further enhance climate change through increased $\mathrm{CO}_{2}$ and $\mathrm{CH}_{4}$ emissions (Davidson and Janssens, 2006; Tarnocai, 2006; Ise et al., 2008; Dorrepaal et al., 2009; $\mathrm{Wu}$ and Roulet, 2014). However, the increasing atmospheric $\mathrm{CO}_{2}$ concentration and temperature may also promote increased primary production and shifts in vegetation ecozones, compensating for the additional C loss from soil respiration (Camill and Clark, 2000; Ward et al., 2013; Wang et al., 2015). Wu and Roulet (2014) showed that fens, which rely on external inputs of water, may be particularly sensitive to changes in surface hydrology. Overall, large uncertainties prevail in the future carbon budget of peatlands and its feedback to climate change (McGuire et al., 2009).

Earth system models (ESMs) simulate the global C cycle and feedbacks to climate and are used to make future climate projections. Poor representation of processes related to the $\mathrm{C}$ cycle in peatlands and organic soil types was identified as one of the key reasons for inaccuracies in simulated soil organic mass and heterotrophic respiratory fluxes in the ESMs used in CMIP5 (Todd-Brown et al., 2013). Recognizing the importance of representing organic soils in the high latitudes, progress has been made recently to integrate peatlands, wetlands and permafrost into coupled global climate-C models. For example, several versions of the Lund-Potsdam-Jena (LPJ) model, a global dynamic vegetation model, have incorporated wetlands or peatlands to simulate global methane emissions (Wania et al., 2009a, b), the spatial expansion and C sequestration of peatlands (Spahni et al., 2013) and wetlands (Kleinen et al., 2012; Schuldt et al., 2013) during the Holocene, and the water and energy cycles in permafrost (Ekici et al., 2014). The simulation of the global spatial distribution of wetlands and permafrost and the long-term $\mathrm{C}$ sequestration of peatlands improved the simulations of soil temperature and water content (e.g. Wania et al., 2009a). However, the models were not evaluated on fine temporal and spatial scales because they were designed for capturing the long-term $\mathrm{C}$ accumulation. On the other hand, several peatland models have been developed and evaluated for individ- ual sites. For example, the McGill Wetland Model (MWM) simulates the $\mathrm{C}$ exchange in Degerö Stormyr and the Mer Bleue bog (St-Hilaire et al., 2010); the peatland version of the General Ecosystem Simulator - Model of Raw Humus, Moder and Mull (GUESS-ROMUL) simulates the variation of net ecosystem production (NEP) with water table position in a fen (Yurova et al., 2007); and the PEATBOG model simulates $\mathrm{C}$ and $\mathrm{N}$ cycles in peatlands, specifically the Mer Bleue bog (Wu et al., 2013). These models have been shown to reproduce well the processes occurring in the peatlands that they were designed for. However, conclusions drawn from these studies about the global implications of peatlands on climate change are often obtained from scaling up the results of the site-level sensitivity analyses and have high uncertainties.

The coupled Canadian Land Surface Scheme (CLASS) (Verseghy, 2012) and the Canadian Terrestrial Ecosystem Model (CTEM) (Melton and Arora, 2014) constitute the land surface component of the family of Canadian Earth system models (CanESMs). The objective of this study is to introduce peatlands into the latest coupled system of CLASS version 3.6 and CTEM version 2.0 (Melton and Arora, 2016). In this paper we present the functional and structural modifications made to the CLASS-CTEM modelling framework and the explicit site-level evaluation of the energy, water and $\mathrm{C}$ balances in varied peatlands that are located in typical northern peatland regions: North America, Eurasia and Siberia.

\section{Model description}

CLASS was first developed in the late 1980s for inclusion in the Canadian global climate model (GCM) (Verseghy, 1991; Verseghy et al., 1993), and has been under continuous development since then. It simulates the energy and water balances of the components of the land surface, mainly the temperatures and liquid and frozen water contents of the vegetation, snow and soil for four sub-areas of each grid cell (bare soil, vegetation covered ground, snow covered ground and vegetation over snow), at a time step of 15-30 min. The model has been parameterized for mineral, organic or mixed soil types (Letts et al., 2000). The organic soil parameterization significantly improved the simulations of soil water and energy balances in peatlands and other organic soils (Comer et al., 2000; Bellisario et al., 2000).

CTEM simulates the terrestrial ecosystem $C$ cycle for nine plant functional types (PFTs) and soil through photosynthesis, autotrophic and heterotrophic respiration based on parameterizations developed by Arora (2003) and Arora and Boer (2005). CTEM's treatment of soil moisture and soil carbon pools showed comparatively high correlations with the biome soil pool and turnover time among ESMs (ToddBrown et al., 2013). These processes determine the flow of carbon in and out of model's three live vegetation components of leaves, stems and roots and two dead carbon pools 
of litter and soil organic matter. CTEM versions 1.2 and above have an improved ability to capture the regional heterogeneity in land cover using a mosaic approach (Melton and Arora, 2014), which matches the similar capability in CLASS. When coupled to CLASS, the structural attributes of vegetation, such as the leaf area index (LAI), root depth, and vegetation height that are calculated in CTEM, are passed to CLASS and used in its calculations of the energy and water balance. The photosynthesis in CTEM directly controls the stomatal activity and the associated stomatal resistance of the PFTs and thus affects the energy and water exchanges at the surface in CLASS. Photosynthesis and leaf respiration are modelled at the CLASS time step of 15-30 min, whereas the rest of the terrestrial ecosystem processes are modelled at a daily time step.

To account for the eco-hydrological and biogeochemical interactions among vegetation, atmosphere and soil in peatlands, the following modifications were made to the coupled CLASS3.6-CTEM2.0 modelling framework:

1. The top soil layer was characterized as a moss layer with a higher heat and hydraulic capacity than a mineral soil layer. The moss layer buffers the exchange of energy and water at the soil surface and regulates the soil temperature and moisture (Turetsky et al., 2012).

2. Three peatland vascular PFTs (evergreen shrubs, deciduous shrubs and sedges) as well as mosses were added to the existing nine CTEM PFTs. These peatlandspecific PFTs are adapted to cold climate and inundated soil with optimized plant structure (shoot/root ratio, rooting depth), growth strategy and metabolic acclimations to light, water and temperature.

3. We considered the soil inundation stress on microbial respiration in the litter $\mathrm{C}$ pool. The original CTEM assumed that litter respiration was not affected by oxygen deficit as a result of flooding, since litter was always assumed to have access to air. This assumption does not hold for peatlands where high water table positions occur routinely.

4. To provide the framework for future runs coupled to the global earth system model, we separated the soil C balance and heterotrophic respiration (HR) calculations for peatland and non-peatland fractions for each grid cell in the global model. Over the non-peatland fraction, we use the original CTEM approach that aggregates the HR from each PFT weighted by the fractional cover. Over the peatland fraction the soil $\mathrm{C}$ pool and decomposition are controlled by the water table position, following the two-compartment approach used in the MWM (StHilaire et al., 2010).

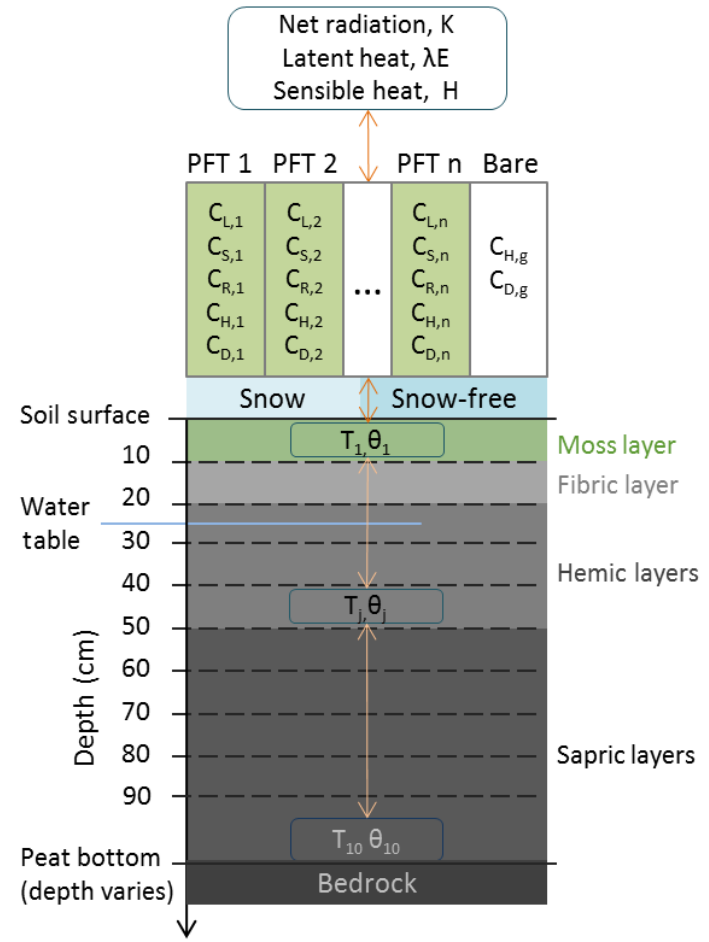

Figure 1. Schematic diagram of the peatland CLASS-CTEM model with 12 PFTs and 10 soil layers. The symbols $C, T$, and $\theta$ represent carbon, temperature, and soil water content respectively. The subscripts L, S, R, H, and D represent leaf, stem, root, fresh litter, and old litter respectively.

\subsection{Soil layers}

The water table depth (WTD) in natural peatlands fluctuates seasonally from above the soil surface to the top of the permanently saturated soil layer, which is often referred to as the boundary between acrotelm and catotelm. The boundary is usually estimated to be $30 \mathrm{~cm}$ below the soil surface in wetlands (Canada Committee on Ecological (Biophysical) Land Classification: National Wetland Working Group, 1997), and has been widely used as the bottom of the first soil layer in two-layer soil decomposition models (e.g. Granberg et al., 1999; Yurova et al., 2007; Spahni et al., 2013). To capture the effect of the fluctuating water table on the transfer of water and energy within the soil, we used a multi-layer configuration rather than the standard three-layer configuration of the soil layers in CLASS. We assigned nine organic soil layers, each $10 \mathrm{~cm}$ thick, at the top of the soil profile and a 10th soil layer from $90 \mathrm{~cm}$ down to the bottom of the organic soil (Fig. 1). Moss was treated as the top first soil layer and the substrate below the 10th soil layer was considered as bedrock. Mineral soil was not included. 


\subsection{A moss layer as the first soil layer}

The standard configuration of soil layers in CLASS consists of three layers with thickness of $0.10,0.25$, and $3.75 \mathrm{~m}$. Organic soil in CLASS was parameterized by Letts et al. (2000) as fibric, hemic and sapric peat in the three soil layers respectively, representing fresh, moderately decomposed and highly decomposed organic matter. Tests of CLASS on peatlands revealed improved performance in the energy simulations for fens and bogs with this organic soil parameterization. However, the model overestimated energy and water fluxes at bog surfaces during dry periods due to the neglect of the moss cover (Comer et al., 2000).

To take into account the interaction amongst the moss and the soil layers and the overlying atmosphere for energy and water transfer, we added a new soil layer $0.10 \mathrm{~m}$ thick above the fibric organic soil to represent living and dead peatland bryophytes, such as Sphagnum mosses and true mosses (Bryopsida). The physical characteristics of mosses differ from those of either the shoots or the roots of vascular plants (Rice et al., 2008). In particular, mosses can hold more than $30 \mathrm{~g}$ of water per gram of biomass (Robroek et al., 2009). More than $90 \%$ of the moss leaf volume is occupied by the waterholding hyaline cells (Rice et al., 2008), which retain water even when the water table depth declines to $1-10 \mathrm{~m}$ below the surface (Hayward and Clymo, 1982).

The parameter values of the moss layer for water and energy properties were derived from a number of recent experiments measuring the hydraulic properties of mosses (Price et al., 2008; Price and Whittington, 2010; McCarter and Price, 2012) (Table 1). Living mosses range from 2-3 to over $5 \mathrm{~cm}$ in height (Rice et al., 2008) and have lower values of dry bulk density and field capacity than fibric peat (Price et al., 2008). Compared to fibric peat, the saturated hydraulic conductivity of living moss is higher by orders of magnitude (Price et al., 2008) and the thermal conductivity is more affected by the water content (O'Donnell et al., 2009). To fully account for the effect of mosses, we set the depth of the living moss $\left(z_{\mathrm{m}}\right)$ within the top soil (i.e. moss) layer to $3 \mathrm{~cm}$ for fens and $4 \mathrm{~cm}$ for bogs, and interpolated its water content $w_{\mathrm{m}}(\mathrm{kg}$ water $(\mathrm{kg}$ dry mass $)^{-1}$ ) from the water content of the overall layer $\theta_{1,1}$ $\left(\mathrm{m}^{3}\right.$ water $\left.(\mathrm{m} \mathrm{soil})^{-3}\right)$ and the depth of the living moss:

$w_{\mathrm{m}}=\frac{z_{\mathrm{m}} \theta_{\mathrm{l}, 1} \rho_{\mathrm{w}}}{B_{\mathrm{m}}}$

where the dry moss biomass $\left(B_{\mathrm{m}}\right)$ is converted from moss $\mathrm{C}$ $\left(\mathrm{C}_{\mathrm{m}}\right)$ using the standard conversion factor of $0.46 \mathrm{~kg} \mathrm{C}$ per $\mathrm{kg}$ dry biomass, $\theta_{1,1}\left(\mathrm{~m}^{3} \mathrm{~m}^{-3}\right)$ is the liquid water content of the top soil layer, and $\rho_{\mathrm{w}}$ is the density of water $\left(1000 \mathrm{~kg} \mathrm{~m}^{-3}\right)$. The maximum and minimum moss water contents were estimated from a number of observed moss water contents (e.g. Williams and Flanagan, 1998; Robroek et al., 2009). In CLASS, evaporation at the soil surface is controlled by a soil evaporation efficiency coefficient $\beta$ (Verseghy, 2012). This parameter is calculated from the liquid water content and the field capacity of the first soil layer following Lee and Pielke (1992). For peatlands, $\beta$ was assumed to be regulated by the relative moisture of the living moss rather than the ratio of relative liquid water content of the first soil layer:

$\beta=0.25\left[1-\cos \left(\frac{w_{\mathrm{m}}-w_{\mathrm{m}, \min }}{w_{\mathrm{m}}-w_{\mathrm{m}, \max }}\right)\right]^{2}$,

where $w_{\mathrm{m}}, w_{\mathrm{m}, \max }$, and $w_{\mathrm{m}, \min }$ are the water content and the maximum and minimum water contents of the living moss in $\mathrm{kg}$ water (kg dry mass $)^{-1}$.

\subsection{Primary production of mosses}

Mosses are an important contributor to the primary production and the $\mathrm{C}$ sequestration in peatlands, owing to the low decomposability of the moss tissue. Sphagnum in peatlands grows at 20-1600 $\mathrm{g}$ biomass $\mathrm{m}^{-2} \mathrm{yr}^{-1}$ and accounts for about $50 \%$ of the total peat volume (Turetsky, 2003). We have modified CTEM to include a moss $\mathrm{C}$ pool and moss litter pool along with the related $\mathrm{C}$ fluxes, i.e. photosynthesis, autotrophic respiration, heterotrophic respiration, and humification. The net photosynthesis of moss $\left(G_{\mathrm{m}}\right)$ is calculated from the gross photosynthesis $\left(G_{0, \mathrm{~m}}\right)$ and dark respiration $\left(R_{\mathrm{d}, \mathrm{m}}\right)$ :

$G_{\mathrm{m}}=G_{0, \mathrm{~m}}-R_{\mathrm{d}, \mathrm{m}}$.

The moss photosynthesis and dark respiration are calculated using the Farquhar (1989) biochemical approach following the MWM (St-Hilaire et al., 2010) and CTEM (Melton and Arora, 2016), with modifications for integration with CLASS-CTEM and moss phenology. The leaf-level gross photosynthesis rate $G_{0, \mathrm{~m}}\left(\mu \mathrm{mol} \mathrm{CO} \mathrm{C}^{-2} \mathrm{~s}^{-1}\right)$ is obtained as the minimum of the transportation limited photosynthesis rates $\left(J_{S}\right)$ and the first root of the quadratic solution of the light-limited rate $\left(J_{e}\right)$ and the Rubisco limited rate $\left(J_{c}\right)$. A logistic factor $(\varsigma)$ is added with values 0 or 1 to introduce a seasonal control of moss photosynthesis. In the MWM, spring photosynthesis starts when the snow depth is below $0.05 \mathrm{~m}$ and the soil temperature at $5 \mathrm{~cm}$ depth goes above $0.5^{\circ} \mathrm{C}$ (Moore et al., 2006). Since in our case CLASS sets the minimum depth for melting, discontinuous snow to $0.10 \mathrm{~m}$, this limits the spring photosynthesis to starting only once the snow is completely melted.

$$
\begin{aligned}
& G_{0, \mathrm{~m}}= \\
& \quad \varsigma \min \left(J_{s}, \frac{\left(J_{c}+J_{e}\right) \pm \sqrt{\left(J_{c}+J_{e}\right)^{2}-4\left(J_{c}+J_{e}\right)}}{2}\right)
\end{aligned}
$$

The dark respiration in mosses $\left(R_{\mathrm{d}, \mathrm{m}}\right)$ is calculated as a function of the base dark respiration rate $\left(R_{\mathrm{d}, \mathrm{m}, 0}\right)$, which has a value of $1.1 \mu \mathrm{mol} \mathrm{m}{ }^{-2} \mathrm{~s}^{-1}$ (Adkinson and Humphreys, 2011) scaled by the moss moisture $\left(f_{\mathrm{m}, \mathrm{rd}}\right)$ and soil temperature functions $\left(f_{T, \text { rd }}\right)$. The moss moisture function is based on the volumetric water content of the moss, $\theta_{\mathrm{m}}(\mathrm{kg}$ water $(\mathrm{kg}$ 
Table 1. Physical properties of organic soil types.

\begin{tabular}{|c|c|c|c|c|c|c|c|c|}
\hline $\begin{array}{l}\text { Soil } \\
\text { type }\end{array}$ & $\begin{array}{r}\text { Soil } \\
\text { depth } \\
(\mathrm{cm})\end{array}$ & $\begin{array}{r}\text { Pore } \\
\text { volume } \\
\left(\mathrm{m}^{3} \mathrm{~m}^{-3}\right)\end{array}$ & $\begin{array}{r}\text { Retention } \\
\text { capacity } \\
\left(\mathrm{m}^{3} \mathrm{~m}^{-3}\right)\end{array}$ & $\begin{array}{r}\text { Residual } \\
\text { water content } \\
\left(\mathrm{m}^{3} \mathrm{~m}^{-3}\right)\end{array}$ & $\begin{array}{r}\text { Clapp and } \\
\text { Hornberger } \\
\text { parameter } b\end{array}$ & $\begin{array}{r}\text { Saturated hydraulic } \\
\text { conductivity } \\
\left(\mathrm{m} \mathrm{s}^{-1}\right)\end{array}$ & $\begin{array}{r}\text { Soil moisture } \\
\text { suction at } \\
\text { saturation }(\mathrm{m})\end{array}$ & $\begin{array}{r}\text { Heat } \\
\text { capacity } \\
\left(\mathrm{J} \mathrm{m}^{-3} \mathrm{~K}^{-1}\right)\end{array}$ \\
\hline Moss & $0-10$ & $0.980^{\mathrm{a}}$ & & $0.010^{\mathrm{c}}$ & 2.3 & $0.183 \times 10^{-2, d}$ & & $2.5 \times 10^{6, \mathrm{e}}$ \\
\hline Fibric & $10-20$ & 0.935 & 0.275 & 0.040 & 2.7 & $0.280 \times 10^{-3}$ & 0.0103 & $2.5 \times 10^{6}$ \\
\hline Hemic & $20-50$ & 0.880 & 0.625 & 0.150 & 6.1 & $0.200 \times 10^{-5}$ & 0.0102 & $2.5 \times 10^{6}$ \\
\hline Sapric & $>60$ & 0.830 & 0.705 & 0.220 & 12.0 & $0.100 \times 10^{-6}$ & 0.0101 & $2.5 \times 10^{6}$ \\
\hline
\end{tabular}

${ }^{\mathrm{a}}$ O'Donnell et al. (2009). ${ }^{\mathrm{b}}$ Price and Whittington (2010). ${ }^{\mathrm{c}}$ McCarter and Price (2012). ${ }^{\mathrm{d}}$ Price et al. (2008). ${ }^{\mathrm{e}}$ Beringer et al. (2001).

dry mass $)^{-1}$ ). The MWM models the relation between water content in mosses and dark respiration with optimal water content at $5.8 \mathrm{~g}$ water per $\mathrm{g}$ dry weight, following the approach in Frolking et al. (1996). We modified the relation for water content above the optimal water content, based on a recent discovery of a weak linear positive relation between the dark respiration rate and the water content above the optimal water content during the late summer and fall (Adkinson and Humphreys, 2011):

$R_{\mathrm{d}, \mathrm{m}}=R_{\mathrm{d}, \mathrm{m}, 0} f_{\mathrm{m}, \mathrm{rd}} f_{T, \mathrm{rd}}$,

$f_{T, \mathrm{rd}}=\left(3.22-\left(0.046 \cdot T_{\mathrm{moss}}\right)^{\left(T_{\mathrm{moss}}-25 / 10\right)}\right.$,

$f_{\mathrm{m}, \mathrm{rd}}= \begin{cases}0, & \theta_{\mathrm{m}}<0.4 \\ 0.35 \theta_{\mathrm{m}}^{2 / 3}-0.14, & 0.4 \leq \theta_{\mathrm{m}}<5.8 \\ 0.01 \theta_{\mathrm{m}}+0.942, & 5.8<\theta_{\mathrm{m}} .\end{cases}$

Photosynthetic photon flux density (PPFD) is measured by the photosynthetically active radiation (PAR), which is defined as the solar radiation between 0.4 to $0.7 \mu$ mol that can be used by plants via photosynthesis. In the coupled CLASSCTEM system, the PAR received by the moss $\left(\mathrm{PAR}_{\mathrm{m}}\right.$, unit $\mu$ mol protons $\mathrm{m}^{-2} \mathrm{~s}^{-1}$ ) is converted from the visible shortwave radiation reaching the ground $\left(K_{* \mathrm{~g}}\right.$, unit $\left.\mathrm{W} \mathrm{m}^{-2}\right)$ in CLASS by a factor of $4.6 \mu \mathrm{mol} \mathrm{m}^{-2} \mathrm{~s}^{-1}$ per $\mathrm{W} \mathrm{m}^{-2}$ (McCree, 1972). $K_{* \mathrm{~g}}$ is a function of the incoming short-wave radiation $\left(K \downarrow\right.$, unit: $\left.\mathrm{W} \mathrm{m}^{-2}\right)$, the surface albedo $\left(\alpha_{\mathrm{g}}\right)$, and the canopy transmissivity $\left(\tau_{\mathrm{c}}\right)$ :

$K_{* \mathrm{~g}}=K \downarrow \tau_{\mathrm{c}}\left(1-\alpha_{\mathrm{g}}\right)$.

The energy uptake by the moss layer is thus a function of the total incoming short-wave radiation, the aggregated LAI of the PFTs present, the snow depth, the fractional vegetation cover, and the soil water content (Verseghy, 2012). In peatland $\mathrm{C}$ models that do not consider vegetation dynamics, the transmissivity of the vegetation canopy is usually assumed to be constant (e.g. St-Hilaire et al., 2010). Compared with such models, CLASS enables a more detailed representation of light incident on the moss surface since it includes partitioning of direct/diffuse and visible/near-IR radiation, PFTspecific transmissivities, and time-varying LAI and fractional PFT coverages (Verseghy, 2012).

\subsection{Peatland-specific PFTs}

CLASS normally categorizes the global vegetation into four broad PFTs that differ in their structure and intra-annual development cycles: needleleaf trees (NDL), broadleaf trees (BDL), crops, and grasses. CTEM further subdivides each PFT in CLASS into PFTs that vary in their phenology, physiology, and their $\mathrm{C}$ assimilation rates: evergreen NDL, deciduous NDL, evergreen BDL, deciduous cold BDL, deciduous dry BDL, C3 crops, C4 crops, C3 grasses, and C4 grasses. The evergreen broadleaf PFTs and $\mathrm{C} 3$ grasses have been parameterized primarily for tropical and temperate vegetation types that are not representative of peatland plants. Therefore, we introduced three new PFTs for peatlands: evergreen shrubs, deciduous shrubs, and sedges. Evergreen shrubs, for example the ericaceous shrubs, are the common dominant vascular plants in bogs and poor fens while deciduous shrubs, such as the betulaceous shrubs, often dominate rich fens. Both shrubs are categorized as broadleaf trees in CLASS morphologically, but their phenological and physiological characteristics are more similar to those of needleleaf trees. The shrub tundra ecosystem is situated adjacent to needleleaf forest in the Northern Hemisphere (Kaplan et al., 2003) and they share similar responses to climate in ESMs (e.g. Bonan et al., 2002). Table 2 lists the key parameters for the peatland PFTs used in this model. (The photosynthesis and autotrophic respiration of vascular PFTs are modelled the same as in the original CTEM.)

\subsection{Heterotrophic respiration}

Over the non-peatland fraction, HR is calculated as the sum of the respiration from litter and soil carbon pools as in the original version of CTEM (Arora, 2003). The soil C pool over the non-peatland areas is assumed to be exponentially distributed with depth (Arora, 2003). In peatlands a large amount of humic soil is generally located in the permanently saturated zone and the bulk density increases with soil depth (Loisel and Garneau, 2010). Thus, the assumption of exponentially decreasing distribution of $\mathrm{C}$ content with increasing soil depth is not valid in peatlands. We used a quadratic equation to calculate the distribution of soil $\mathrm{C}$ content over 
Table 2. Descriptions of vegetation characteristics for the four peatland PFTs. A dash (-) indicates the parameter is inapplicable to that PFT.

\begin{tabular}{|c|c|c|c|c|c|c|c|}
\hline $\begin{array}{l}\text { Parameter } \\
\text { name }\end{array}$ & Description & Unit & Moss & $\begin{array}{r}\text { Evergreen } \\
\text { shrubs }\end{array}$ & $\begin{array}{r}\text { Deciduous } \\
\text { shrubs }\end{array}$ & Sedge & References \\
\hline abar & $\begin{array}{l}\text { Parameter determining root dis- } \\
\text { tribution }\end{array}$ & - & - & 8.50 & 9.50 & 9.50 & 1 \\
\hline avertmas & $\begin{array}{l}\text { Average root biomass for esti- } \\
\text { mating rooting profile }\end{array}$ & $\mathrm{KgCm}^{-2}$ & - & 1.50 & 1.20 & 0.20 & 1 \\
\hline bsratelt & Litter respiration rate at $15^{\circ} \mathrm{C}$ & $\mathrm{KgC} \mathrm{kg} \mathrm{C}^{-1} \mathrm{yr}^{-1}$ & - & 0.4453 & 0.5986 & 0.5260 & 2 \\
\hline bsratesc & Soil $\mathrm{C}$ respiration rates at $15^{\circ} \mathrm{C}$ & $\mathrm{KgC} \mathrm{kg} \mathrm{C}^{-1} \mathrm{yr}^{-1}$ & - & 0.0208 & 0.0208 & 0.0100 & 2 \\
\hline bsrtroot & $\begin{array}{l}\text { Base respiration rates at } 15^{\circ} \mathrm{C} \\
\text { for root }\end{array}$ & $\mathrm{KgC} \mathrm{kg} \mathrm{C}^{-1} \mathrm{yr}^{-1}$ & - & 0.5000 & 0.2850 & 0.1000 & 2 \\
\hline bsrtstem & $\begin{array}{l}\text { Base respiration rates at } 15^{\circ} \mathrm{C} \\
\text { for stem }\end{array}$ & $\mathrm{Kg} \mathrm{Ckg} \mathrm{C}^{-1} \mathrm{yr}^{-1}$ & - & 0.0700 & 0.0335 & - & 2 \\
\hline cdlsrtmx & $\begin{array}{l}\text { Maximum loss rate for cold } \\
\text { stress }\end{array}$ & day $^{-1}$ & - & 0.10 & 0.30 & 0.15 & 2 \\
\hline drlsrtmx & $\begin{array}{l}\text { Maximum loss rate for drought } \\
\text { stress }\end{array}$ & day $^{-1}$ & - & 0.006 & 0.005 & 0.020 & 2 \\
\hline humicfac & $\begin{array}{l}\text { Humification factor used for } \\
\text { transferring C from litter into } \\
\text { soil C pool }\end{array}$ & - & - & 0.42 & 0.42 & 0.42 & 2 \\
\hline $\mathrm{kn}$ & $\begin{array}{l}\text { Canopy light/nitrogen extinc- } \\
\text { tion coefficient }\end{array}$ & - & - & 0.50 & 0.50 & 0.46 & 2 \\
\hline laimax & Maximum leaf area index & $\mathrm{m}^{2}$ & - & 4.0 & 3.0 & 4.0 & 2 \\
\hline laimin & Minimum leaf area index & $\mathrm{m}^{2}$ & - & 1.0 & 1.0 & 0.01 & 2 \\
\hline lfespany & Leaf life span & year & - & 5.0 & 0.4 & 1.0 & 3 \\
\hline lwrthrsh & $\begin{array}{l}\text { Lower temperature threshold } \\
\text { for cold stress-related leaf loss } \\
\text { rate }\end{array}$ & ${ }^{\circ} \mathrm{C}$ & - & -50.0 & -5.0 & 0.1 & 2 \\
\hline mxrtdpth & Maximum rooting depth & $\mathrm{m}$ & - & 1.00 & 1.00 & 1.00 & 1 \\
\hline rmlcoeff & $\begin{array}{l}\text { Leaf maintenance respiration } \\
\text { coefficient }\end{array}$ & - & - & 0.025 & 0.020 & 0.015 & 2 \\
\hline rmlmoss 25 & $\begin{array}{l}\text { Base dark respiration rate in } \\
\text { mosses }\end{array}$ & $\mu \mathrm{mol} \mathrm{CO} \mathrm{m}^{-2} \mathrm{~s}^{-1}$ & 1.1 & - & - & - & 4 \\
\hline rootlife & Turnover timescale for root & year & - & 11.50 & 12.00 & 2.00 & 2,5 \\
\hline rtsrmin & Minimum root / shoot ratio & - & - & 0.16 & 0.16 & 0.30 & 2,6 \\
\hline stemlife & Turnover timescale for stem & year & - & 65 & 75 & - & 2 \\
\hline Tlow & $\begin{array}{l}\text { Lower temperature limits for } \\
\text { photosynthesis }\end{array}$ & ${ }^{\circ} \mathrm{C}$ & 0.5 & -2.0 & -2.0 & -1.0 & $2,7,8$ \\
\hline Tup & $\begin{array}{l}\text { Upper temperature limits for } \\
\text { photosynthesis }\end{array}$ & ${ }^{\circ} \mathrm{C}$ & - & 34.0 & 34.0 & 40.0 & 2 \\
\hline Vmax & Maximum photosynthesis rate & $\mu \mathrm{mol} \mathrm{CO} \mathrm{m}^{-2} \mathrm{~s}^{-1}$ & ${ }^{10} 6.5,14$ & 60 & 50 & 40 & 4,9 \\
\hline
\end{tabular}

${ }^{a}$ Calibrated based on proper rooting depth. ${ }^{b}$ Adapted from the parameters for evergreen, deciduous needleleaf and C3 grasses. ${ }^{c}$ Bond-Lamberty et al. (2007). ${ }^{\mathrm{d}}$ Williams and Flanagan (1998). ${ }^{e}$ Modified for shrubs so that the root turnover time follows trees $>$ shrubs $>$ grasses. $f$ Calibrated based on Murphy et al. (2009) for the minimum root/shoot ratio of sedge to be lower than grasses. ${ }^{\mathrm{g}}$ Moore et al. (2006). ${ }^{\mathrm{h}}$ Tanja et al. (2003). ${ }^{\mathrm{i}}$ assumed based on literature (Givnish, 2002; Reich et al., 1998) so that $V_{\text {max }}$ values are higher in evergreens than in deciduous and are in line with the values for trees. ${ }^{\mathrm{j}} V_{\max }$ of mosses is 14 in the summer and 6.5 in the remaining time (Williams and Flanagan, 1998).

depth based on an empirically determined bulk density profile (Frolking et al., 2001).

HR over the peatland fraction of a grid cell is modelled using a two-pool approach with a flexible boundary between the pools that depends on the depth of the water table:

$$
\left\{\begin{array}{l}
R_{\mathrm{o}}=C_{\mathrm{SOM}, \mathrm{o}} k_{\mathrm{o}} f_{T, \mathrm{o}} \\
R_{\mathrm{a}}=C_{\mathrm{SOM}, \mathrm{a}} k_{\mathrm{a}} f_{T, \mathrm{a}} f_{\text {anoxic }}
\end{array}\right.
$$

where $\mathrm{o}$ and a denote the oxic and anoxic portions of the soil $\mathrm{C}$ pool respectively. The respiration rate $R$ (unit: $\left.\mu \mathrm{mol} \mathrm{C} \mathrm{m}^{-2} \mathrm{~s}^{-1}\right)$ is obtained from the respiration rate coefficient $k$ ( $\mu \mathrm{mol} \mathrm{kg} \mathrm{C}^{-1} \mathrm{~s}^{-1}$ ), the temperature functions $f_{T}$, the soil $\mathrm{C}$ mass $C_{\mathrm{SOM}}(\mathrm{kg})$, and a scaling factor $f_{\text {anoxic }}$ after 
Frolking et al. (2010, 2001), which represents the inhibition of microbial respiration under anoxic conditions. The value of this parameter is uncertain, varying in those two papers between 0.001, 0.025 and 0.1. Based on calibration runs using two of the data sets described below (MB-Bog and AB-Fen), we adopted a value of 0.025 . $Q_{10}$ is calculated using a hyperbolic tan function of the soil temperatures $\left(T_{\mathrm{S}}\right)$ of the oxic and anoxic zones (Melton and Arora, 2016), which are in turn functions of water table depth (Eq. 10). The $Q_{10}$ values of the anoxic and the oxic zones of the soil are indicated as $Q_{10, \mathrm{a}}$ and $Q_{10, \mathrm{o}}$. The values of $k, f_{T}$, and $C_{\mathrm{SOM}}$ are updated along with the water table depth $\left(z_{\mathrm{wt}}\right.$, unit: $\mathrm{m}$, positive downward) and the peat depth ( $z_{\mathrm{p}}$, unit: $\left.\mathrm{m}\right)$ at each CTEM time step. The equations for $k$ and $C_{\text {SOM }}$ are derived from Fig. 2 in Frolking et al. (2001), and parameterized differently for fens and bogs (Table 3):

$$
\begin{aligned}
& \left\{\begin{array}{c}
\left.f_{T, \mathrm{o}}=Q_{10, \mathrm{o}}^{\left(\int_{0}^{z \mathrm{wt}}\right.} T_{j}-15\right) / 10 \\
f_{T, \mathrm{a}}=Q_{10, \mathrm{a}}^{\left(\int_{z \mathrm{w}}^{z \mathrm{p}} T_{j}-15\right) / 10},
\end{array}\right. \\
& Q_{10}=1.44+0.56 \tanh \left[0.075\left(46.0-T_{\mathrm{s}}\right)\right],
\end{aligned}
$$

$$
\left\{\begin{aligned}
T_{\mathrm{s}, \mathrm{o}} & =\int_{0}^{z_{\mathrm{wt}}} T_{j} /\left(z_{\mathrm{wt}}\right) \\
T_{\mathrm{s}, \mathrm{a}} & =\int_{z_{\mathrm{wt}}}^{z_{\mathrm{p}}} T_{j} /\left(z_{\mathrm{p}}-z_{\mathrm{wt}}\right),
\end{aligned}\right.
$$

$k_{\mathrm{o}}= \begin{cases}0, & z_{\mathrm{wt}}<0 \\ k_{1}\left(1-e^{k_{2} z_{\mathrm{wt}}}\right)+k_{3} z_{\mathrm{wt}}, & 0.3>_{z \mathrm{t}} \geq 0 \\ k_{4} e^{k_{5} z_{\mathrm{wt}}}+k_{6} z_{\mathrm{wt}}+k_{7}, & z_{\mathrm{wt}} \geq 0.3,\end{cases}$

$k_{\mathrm{a}}= \begin{cases}k_{4} e^{k_{5} z_{\mathrm{p}}}+10 k_{6} z_{\mathrm{p}}+k_{7}, & z_{\mathrm{wt}}<0 \\ \left|k_{1} e^{k_{2} z_{\mathrm{wt}}}-k_{4} e^{k_{5} z_{\mathrm{p}}}-k_{3} z_{\mathrm{wt}}+k_{8}\right|, & 0.3>z_{\mathrm{wt}} \geq 0 \\ k_{4}\left(e^{k_{5} z P-} e^{k_{5} z \mathrm{wt}}\right)+k_{6}\left(z_{\mathrm{p}}-z_{\mathrm{wt}}\right), & z_{\mathrm{wt}} \geq 0.3,\end{cases}$

$C_{\mathrm{SOM}, \mathrm{o}}=0.487 *\left(k_{9} z_{\mathrm{wt}}^{2}+k_{10} z_{\mathrm{wt}}\right)$,

$C_{\mathrm{SOM}, \mathrm{a}}=C_{\mathrm{SOM}}-C_{\mathrm{SOM}, \mathrm{o}}$,

where 0.487 is a parameter that converts from soil mass to soil $\mathrm{C}$ content. The variation of $k_{\mathrm{o}}$ and $k_{\mathrm{a}}$ with water table depth for bogs and fens is shown in Fig. 2. It will be noted that there is a sharp transition in decomposition rate at a depth of $0.3 \mathrm{~m}$, reflecting the work of Frolking et al. (2001). As noted in Sect. 2.1 above, this value is widely accepted as a representative estimate of the depth dividing the acrotelm and catotelm. In reality, of course, this depth will vary among peatlands. When our peatland model is implemented in climate mode, it is planned that spin-up tests will be run to assess the spatial variability of this depth, and adjustments will be made to Eqs. (13) and (14) if necessary.

As only organic soil is considered in peatlands, the peat soil $\mathrm{C}$ is updated from the humification $\left(\mathrm{C}_{\text {hum }}\right.$, $\left.\mathrm{kg} \mathrm{C} \mathrm{m}^{-2} \mathrm{day}^{-1}\right)$ and soil respiration from the oxic $\left(R_{\mathrm{o}}\right.$ in $\mathrm{kg} \mathrm{C} \mathrm{m}^{-2}$ day $\left.^{-1}\right)$ and anoxic $\left(R_{\mathrm{a}}\right.$ in $\mathrm{kg} \mathrm{C} \mathrm{m}^{-2}$ day $\left.^{-1}\right)$ components during the time step:

$\frac{\mathrm{dC}_{\mathrm{SOM}}}{\mathrm{d} t}=C_{\mathrm{hum}}-R_{\mathrm{o}}-R_{\mathrm{a}}$

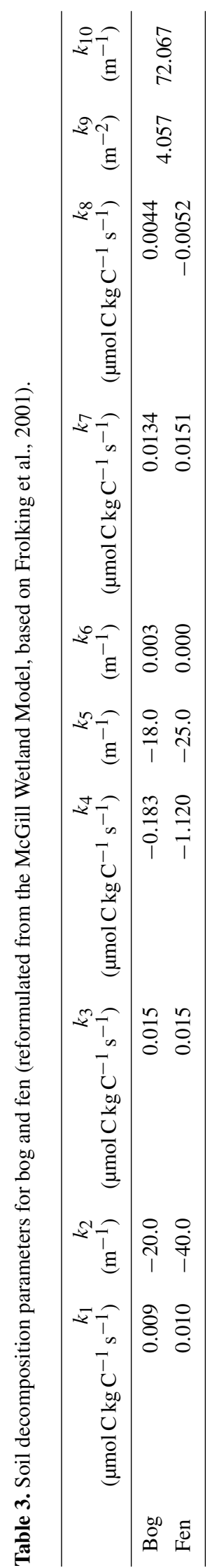

Geosci. Model Dev., 9, 2639-2663, 2016 


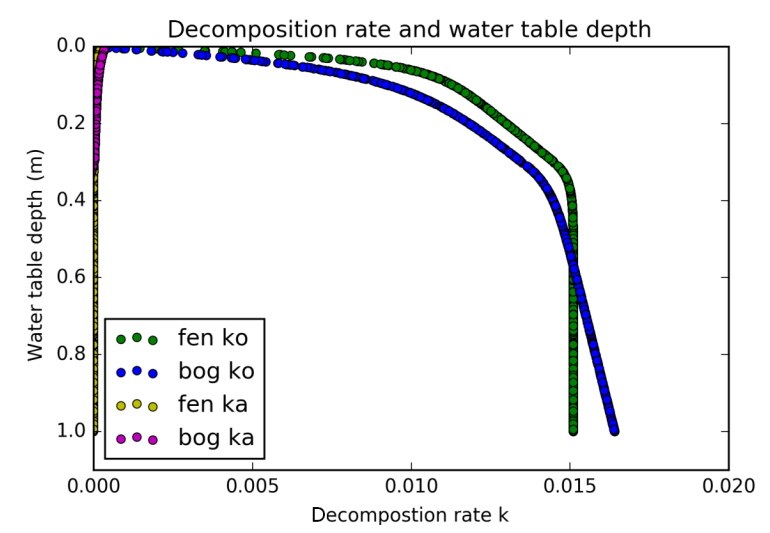

Figure 2. Variation of respiration rate coefficients $k_{\mathrm{O}}$ and $k_{\mathrm{a}}$ with water table depth.

$C_{\text {hum }}$ is calculated as a PFT-dependent fraction of the decomposition rate. Values of this coefficient are shown in Table 2 (variable "humicfac"). At the end of each time step, the peat depth (i.e. the depth of the organic soil) $z_{p}$ is updated from the updated peat $\mathrm{C}$ mass $\left(\mathrm{C}_{\mathrm{SOM}}\right.$ in $\left.\mathrm{kg}\right)$ by solving the quadratic equation

$z_{\mathrm{p}}=\frac{-k_{10}+\sqrt{k_{10}+\frac{4 k_{9} \mathrm{C}_{\mathrm{SOM}}}{0.487}} .}{2 k_{9}}$

The water table depth $z_{\mathrm{wt}}$ is deduced by searching for a soil layer below, which the soil is saturated and above which the soil moisture is at or below the retention capacity with respect to gravitational drainage. Within this soil layer $j, z_{\mathrm{wt}}$ is calculated as

$z_{\mathrm{wt}}=z_{\mathrm{b}, j}-\Delta z\left[\frac{\theta_{\mathrm{l}, j}+\theta_{i, j}-\theta_{\mathrm{ret}, j}}{\theta_{\mathrm{p}, j}-\theta_{\mathrm{ret}, j}}\right]$,

where $\Delta z$ is the thickness of soil layer (unit: $\mathrm{m}$ ), $\theta_{1}$ and $\theta_{i}$ are the liquid and frozen water contents (unit, $\mathrm{m}^{3} \mathrm{~m}^{-3}$ ), $\theta_{\text {ret }}$ and $\theta_{\mathrm{p}}$ are the water retention capacity and the porosity, and $z_{\mathrm{b}}$ (unit: $\mathrm{m}$ ) is the bottom depth of the soil layer.

\section{Evaluation methods and data}

\subsection{Site locations}

The model was applied at eight peatland sites to assess its performance in simulating the water, energy, and C fluxes. The peatlands selected consist of four bogs and four fens (Fig. 3). The bogs are the Auchecorth Moss (UK-Amo), $18 \mathrm{~km}$ south of Edinburgh, Scotland; the Fajemry bog (SEFaj), in the south of Sweden; the Fyodorovskoye bog (RUFyo), about $340 \mathrm{~km}$ north-west of Moscow, Russia; and the Mer Bleue bog (MB-Bog), about $20 \mathrm{~km}$ away from Ottawa, Canada. The fens are the Kaamanen Wetland (FI-Kaa), close to Inari in Finland; the Lompolojänkkä northern boreal fen

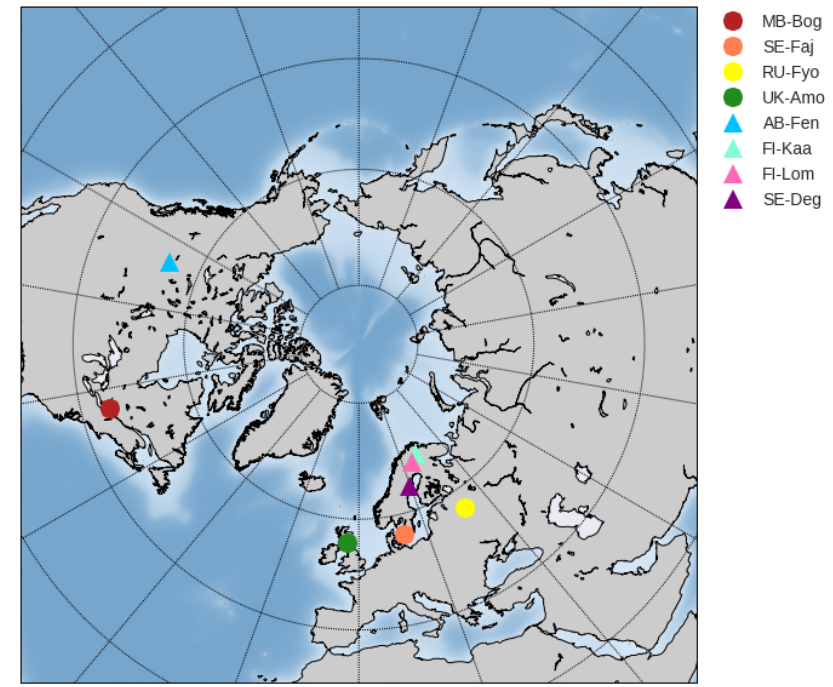

Figure 3. Locations of the test peatlands; closed circles indicate bogs and triangles indicate fens.

(FI-Lom), in northern Finland; the Degerö Stormyr (SE-Deg) near Uppsala, Sweden; and the Alberta western peatland treed fen (AB-Fen), north of Edmonton, Canada. The characteristics of the eight peatlands represented nutrient gradients from ombrotrophic to minerotrophic, elevations between 65 and $581 \mathrm{~m}$ above sea level, mean annual precipitation (MAP) ranging from 473 to $1155 \mathrm{~mm}$ per year, mean annual temperature (MAT) between -1.4 and $10.0^{\circ} \mathrm{C}$ and maximum LAI ranging from 0.7 to 3.5 (Table 4 ).

Data were obtained from the FLUXNET database (http: //fluxnet.ornl.gov/). For each site and for each downloaded variable, the highest available data level was used. The meteorological drivers for the model were obtained from level 4 (gap-filled and quality-controlled) data, except for the wind speed which was obtained from level 3 and surface pressure from level 2 data. Carbon fluxes were obtained from level 4 daily average data when available. The observed GPP and NEP in the FLUXNET database were derived from the observed NEP and the relations between NEP, temperature and photosynthetically active radiation (PAR). The remaining fluxes were averaged from half-hourly level 2 and level 3 data.

In the model evaluation, it must be borne in mind that eddy covariance measurements of turbulent fluxes of energy, water and carbon are subject to inherent uncertainties and errors related to atmospheric conditions such a low turbulence and wind direction, or to equipment malfunction. For this reason we selected a relatively large number of test sites with multi-year data sets, and focused on long-term averages for the validation. We also included in the evaluation variables such as water table depth, soil temperature and snow depth, which are not dependent on turbulent flux measurements. 
Table 4. Descriptions of the test sites.

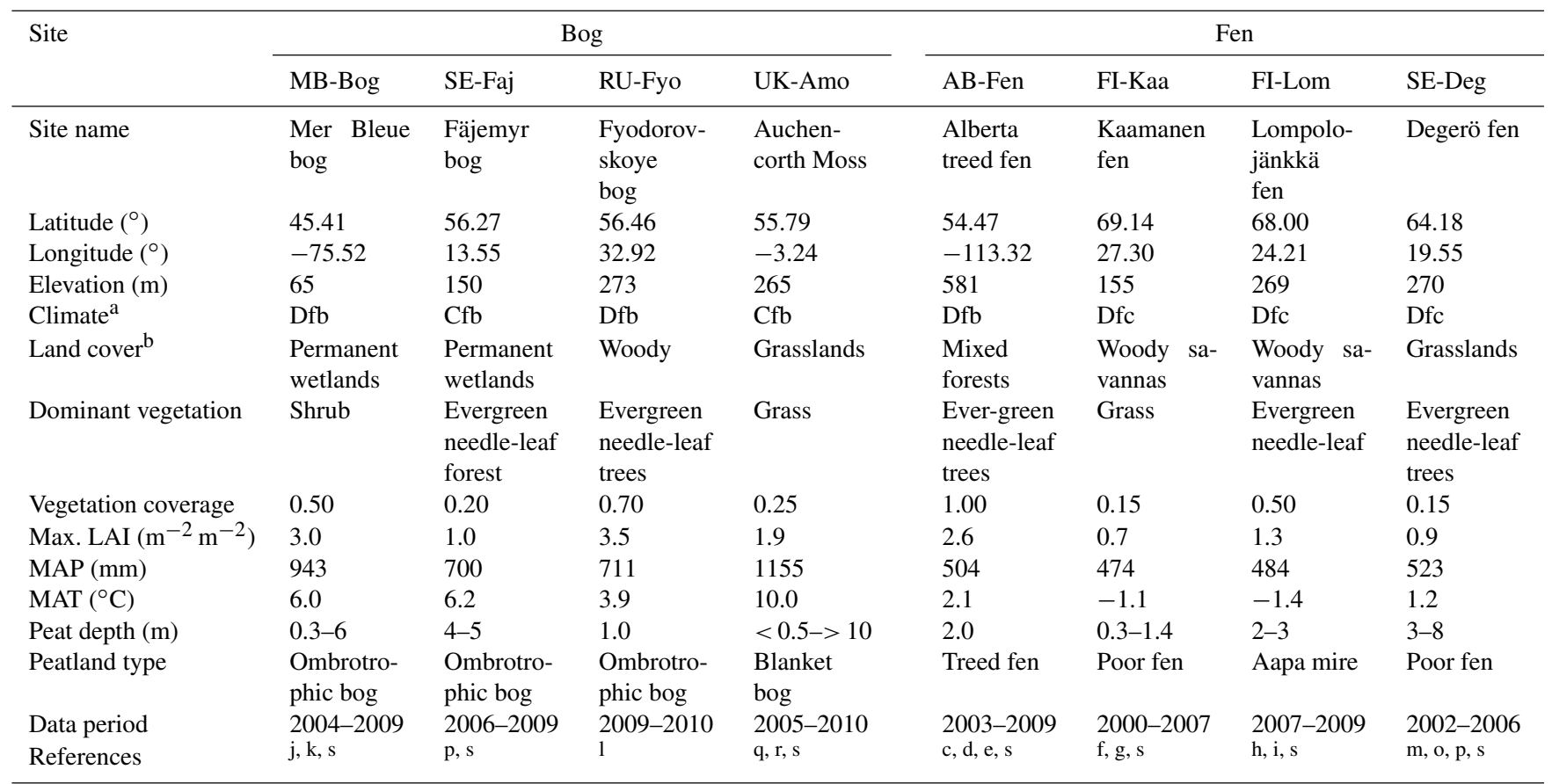

${ }^{a}$ Climate types are classified using the Köppen-Geiger Climate Classification (KCGG) (Kottek et al., 2006). Dfb is Snow fully humid warm summer; Dfc is Snow fully humid cool summer; Cfb is Warm temperature fully humid with warm summer. ${ }^{b}$ Land cover is classified using the International Geosphere Biosphere Programme (IGBP) Land Cover Classification. ${ }^{\mathrm{c}}$ Syed et al. (2006).

${ }^{\mathrm{d}}$ Adkinson et al. (2011). ${ }^{\mathrm{e}}$ Flanagan and Syed (2011). ${ }^{\mathrm{f}}$ Aurela et al. (1998). ${ }^{\mathrm{g}}$ Maanavilja et al. (2011). ${ }^{\mathrm{h}}$ Aurela et al. (2009). ${ }^{\mathrm{i}}$ Drewer et al. (2010). ${ }^{\mathrm{j}}$ Moore et al. (2002). ${ }^{\mathrm{k}}$ Bubier et al. (2006).

${ }^{1}$ http://www.eol.ucar.edu/projects/ceop/dm/insitu/sites/neespi/Fyodorovskoye/wetspruce/. ${ }^{\mathrm{m}}$ Sagerfors et al. (2008). ${ }^{\mathrm{n}}$ Laine et al. (2011). ${ }^{\circ}$ Peichl et al. (2014). ${ }^{\mathrm{p}}$ Lund et al. (2007). ${ }^{\mathrm{q}}$ Dinsmore et al. (2010). ${ }^{\mathrm{r}}$ Leith et al. (2014). ${ }^{\mathrm{s}}$ http://fluxnet.ornl.gov.

\subsection{Model initialization and spin-up}

For each site, the FLUXNET database was used to assign values to background variables such as latitude, longitude, peat depth, areal coverage of the three peatland PFTs, and their roughness lengths, visible and near-infrared albedos, and canopy mass. Other CLASS- and CTEM-related vegetation parameters were assigned their standard values, as listed in Table 2. The parameter values for evergreen shrubs, deciduous shrubs and sedge mostly reflected those used for evergreen needleleaf trees, deciduous needleleaf trees and C3 grasses in CTEM respectively. Exceptions were made for some parameters that determine the length or shape and turnover of the stem and root of the PFT and its tolerance to coldness and dryness (Table 2).

Model $\mathrm{C}$ pools in vegetation were spun-up from initial conditions by repeatedly cycling through the inputs for approximately 100 years until the annual mean $\mathrm{C}$ pools in consecutive years differed by less than $5 \%$. The initial soil C mass was calculated from the observation-based estimations of peat depth based on an empirically obtained relation between the soil depth and soil mass (Eq. 15).

\subsection{Observational data sets}

The model was forced with half-hourly measured meteorological data: downwelling short-wave radiation, downwelling long-wave radiation, precipitation, atmospheric pressure, air temperature $\left(T_{\mathrm{a}}\right)$, specific humidity, and wind speed. The measurement heights for the latter three were obtained from the FLUXNET metadata. Data sets ranged in length from 2 to 9 years. The parameters used for model evaluation include water table depth (zWT), snow depth, soil temperature $\left(T_{\mathrm{S}}\right)$, latent heat flux $(\mathrm{QE})$, sensible heat flux $(\mathrm{QH})$, GPP, ER and NEP. Energy and C fluxes were measured every $30 \mathrm{~min}$ using the eddy-covariance (EC) technique. The required downwelling long-wave radiation (LW) was available only at MB-Bog, AB-Fen, SE-Deg, and FI-Lom. For the remaining four sites, LW was estimated following the methods of Crawford and Duchon (1999):

$\mathrm{LW} \downarrow=\left[c_{\mathrm{f}}+\left(1-c_{\mathrm{f}}\right) \varepsilon_{\mathrm{c}}\right] \sigma T_{\mathrm{a}}^{4}$,

where $\sigma$ is the Stefan-Boltzmann constant and $c_{\mathrm{f}}$ is the cloud fraction term ranging between 0 and $1 . c_{\mathrm{f}}$ is estimated as the ratio between the incoming short-wave radiation and the clear-sky solar radiation, which in turn is a function of the locational character of the site, i.e. latitude, longitude, altitude and time zone. $\varepsilon_{\mathrm{c}}$ is the clear-sky emissivity and is estimated 

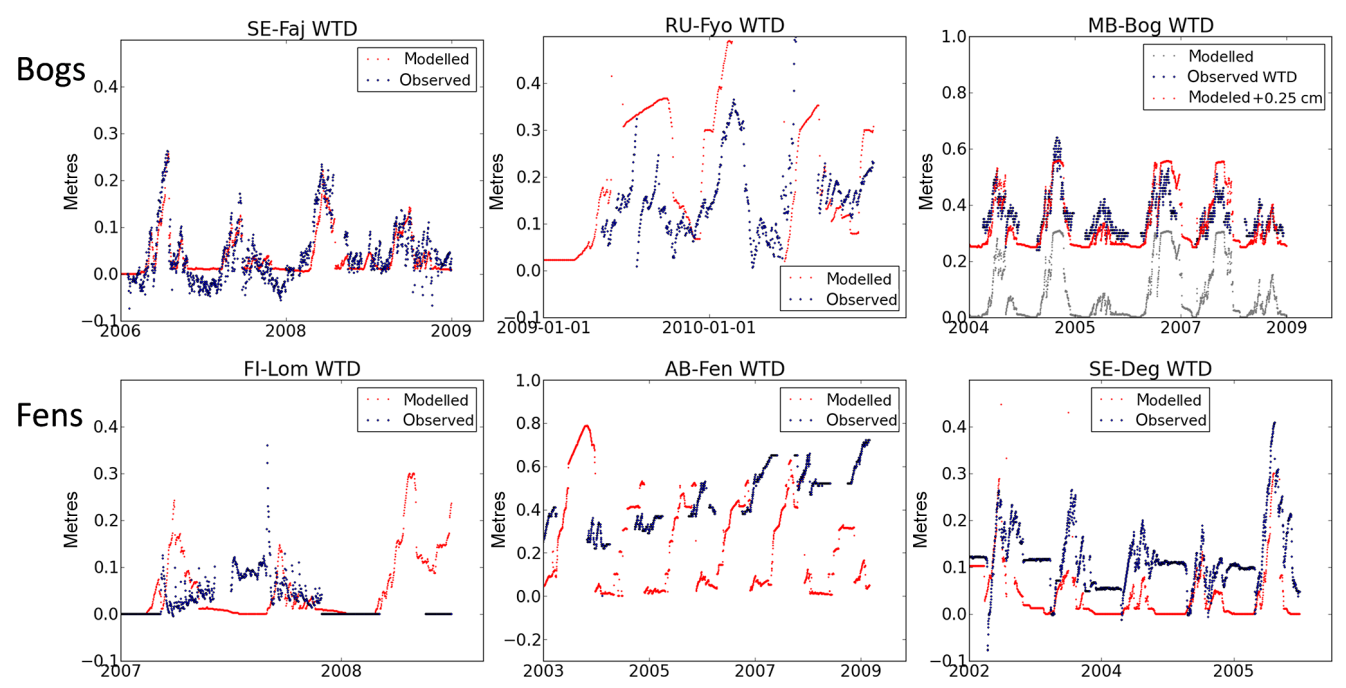

Figure 4. Simulated and observed daily average water table depth (m) in three bogs (MB-Bog, RU-Fyo, SE-Faj) and three fens (AB-Fen, FI-Lom, SE-Deg).

from the vapour pressure $\left(e_{0}\right)$ following Ångström (1918):

$\varepsilon_{c}=0.83-0.18 \times 10^{-0.067 e_{0}}$.

Water table depths were available for three bogs (RU-Fyo, SE-Faj and MB-Bog) and three fens (AB-Fen, FI-Lom, SEDeg) sites and snow depths were available for MB-Bog and AB-Fen only. Soil temperatures were available at 1, 5, 10, 20, $40,80,150$, and $250 \mathrm{~cm}$ below the soil surface at the MB-Bog and at 2, 5, 10,20,50, and $100 \mathrm{~cm}$ below the soil surface at AB-Fen. For the other six sites, the soil temperature was only measured at $5 \mathrm{~cm}$ below the surface.

\subsection{Evaluation methods}

The model was evaluated against observation-based daily sensible and latent heat fluxes at the soil surface, soil water content, water table and snow depth, soil temperature at various depths, and the daily, monthly, and annual C fluxes (GPP, ER, NEP). The root mean square error (RMSE) and linear regression coefficient $\left(r^{2}\right)$ were primarily used for evaluation. Statistical analyses were conducted using the free software package R version 3.1.1 (R Core Team, 2014).

Since the ultimate goal is to apply the model globally in an ESM, further experiments were done to investigate the importance of modelling fens and bogs separately. In the version of the model described above, bogs and fens are distinguished primarily through the parameterization of the control of water table depth on soil decomposition (Table 3). Also, the depth of the living moss $\left(d_{\mathrm{m}}\right)$ is set to $4.0 \mathrm{~cm}$ for bogs and $3.0 \mathrm{~cm}$ for fens. In a first test, the parameters for soil decomposition (Table 3) for bogs were used for the fen sites and those for the fens were used for the bog sites. In a second test, the living moss layer was set to a single fixed value of $3.5 \mathrm{~cm}$ for both bogs and fens. The resulting differences in the surface fluxes and the soil temperatures were then evaluated.

\section{Results and discussion}

\subsection{Water budget terms}

Figure 4 illustrates the simulated daily WTD compared with observations at the six sites where WTD was observed. The model successfully simulated the seasonal dynamics and the zone of fluctuation of the water table in the first two bogs, except for the extremely deep water table observed in RU-Fyo in 2010. Although ponded water is simulated in the model, the simulated WTD did not include the depth of pond above the soil surface, which appears in the observations as a negative value, for example up to $-0.14 \mathrm{~m}$ in the SE-Faj bog during the winter. The simulated WTD of the FI-Lom fen agreed well with the observations after the spring of the second simulated year (2008). The modelled WTD was calculated as the uppermost surface of the liquid water present in the soil, and thus did not account for the potential occurrence of liquid water below the surface frozen soil layer. As a result, the simulated WTD stayed close to the soil surface over the winter when the soil was frozen. The errors in MB-Bog were consistent over time, which was likely a result of the difference between the observed and modelled peat surfaces. The difference in height between hummocks and hollows at the MB-Bog is about $0.25 \mathrm{~m}$ (Lafleur et al., 2005) and the bottom of the fibric peat lies at 0.35 and $0.10 \mathrm{~m}$ below the peat surface for hummock and hollow respectively (Dimitrov et al., 2010). The parameterized MB-Bog, with $0.10 \mathrm{~m}$ of fibric peat, is therefore closer to a hollow (Table 1). Correcting the modelled WTD by $0.25 \mathrm{~m}$ led to a high agreement 

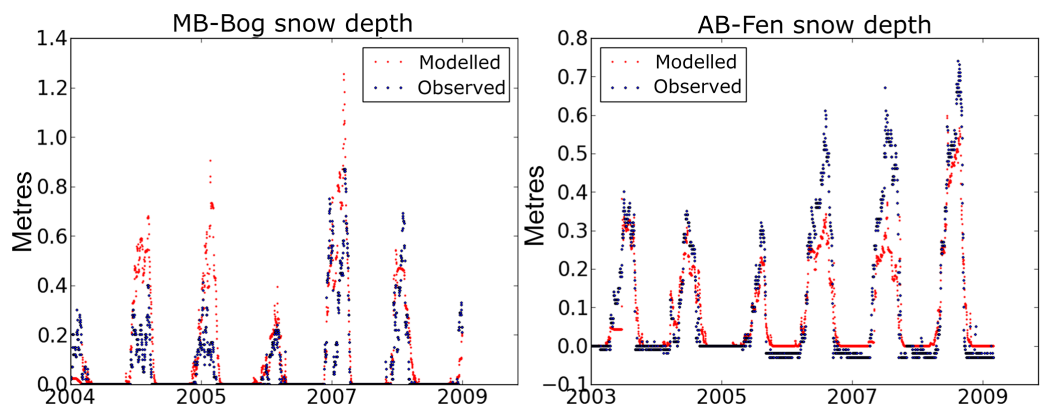

Figure 5. Simulated and observed daily average snow depth (m) in the MB-Bog and the AB-Fen.

with the observed WTD in MB-Bog (Fig. 4). For AB-Fen, the model overestimated the inter-annual fluctuation and did not reproduce the trend of increasing WTD seen in the observations, which was likely associated with the change in vegetation cover. It has been observed that the $A B-F e n$ site is currently changing from a rich fen to a poor fen and is now in a phase of rapid tree establishment and increase in LAI and NEP (Flanagan and Syed, 2011).

The model reproduced the annual variation of snow depth quite well for the bog and fen sites where observations were available (Fig. 5). The errors for the MB bog may be associated with uncertainties in the observed data stemming from the combination of a continuous record from one spot with sporadic snow depth data from other locations on the bog surface (Moore et al., 2006).

\subsection{Energy budget terms}

The model performed similarly well on the daily average $\mathrm{QE}$ and $\mathrm{QH}$ fluxes for multi-year simulations (Table 5, Fig. 6). The RMSEs ranged from 23.0 to $37.7 \mathrm{~W} \mathrm{~m}^{-2}(\mathrm{QH})$ and 27.3 to $79.7 \mathrm{~W} \mathrm{~m}^{-2}(\mathrm{QE})$ for bogs and from 19.6 to $41.5 \mathrm{~W} \mathrm{~m}^{-2}(\mathrm{QH})$ and 15.8 to $31.5 \mathrm{~W} \mathrm{~m}^{-2}(\mathrm{QE})$ for fens. When organic soils were first introduced into CLASS by Comer et al. (2000), RMSEs ranged from 16.9 to $47.7 \mathrm{~W} \mathrm{~m}^{-2}$ $(\mathrm{QH})$ and 23.1 to $65.6 \mathrm{~W} \mathrm{~m}^{-2}(\mathrm{QE})$ for fens and 67.4 to $182.5 \mathrm{~W} \mathrm{~m}^{-2}(\mathrm{QH})$ and 78.1 to $153.8 \mathrm{~W} \mathrm{~m}^{-2}(\mathrm{QE})$ for bogs. Our new model shows a consistent improvement in the energy flux simulations, especially for bogs, where the surface moss cover plays an essential role in regulating the thermal and hydraulic conductivities (Turetsky et al., 2012).

The mean $r^{2}$ coefficient between the simulated and observed daily average QH was 0.47 and the highest $r^{2}$ was 0.89 for the AB-Fen site. The poorest agreement in $\mathrm{QH}$ occurred in the FI-Kaa fen and the UK-Amo bog. The error in FI-Kaa peaked in the winters of 2002 and 2007 when the snow depth exceeded $0.8 \mathrm{~m}$ (not shown). Turbulent fluxes over deep, cold snow packs are notoriously difficult to model accurately (Bazile et al., 2013). In the case of QE, the mean $r^{2}$ for the eight sites is 0.52 , and rises to 0.60 if the outlier UK-Amo is disregarded. The large bias of $\mathrm{QH}$ and $\mathrm{QE}$ at
UK-Amo is thought to be partially attributable to instrumental errors, given the scattered data cloud of the observed QE in 2006 (not shown).

The simulated daily average soil temperature at $5 \mathrm{~cm}$ depth across the eight sites agreed well with the observations, with $r^{2}$ values between 0.77 and 0.98 . The comparatively low value found for UK-Amo is perhaps linked to the errors in QE noted above. The RMSE ranged from 1.7 to $4.7^{\circ} \mathrm{C}$ with a mean of $3.1^{\circ} \mathrm{C}$. This is larger than the RMSE range of 0.7 to $2.3{ }^{\circ} \mathrm{C}$ found for LPJ-WHy v1.2 by Wania et al. (2009a), yet is encouraging considering that the simulation periods for our sites ranged from 2 to 9 years compared to the 1 year simulation with LPJ-WHy, and that we included eight sites in our evaluation compared with two peatland sites for LPJWHy. Our model was able to capture the seasonal variation in soil temperature at different depths down to the bedrock. Figure 7 compares the modelled soil temperatures against the observations at $5,40,80 \mathrm{~cm}$, and $250 \mathrm{~cm}$ depths for the Mer Bleue bog, where good-quality data are available for soil $T$ at various depths.

\subsection{Carbon fluxes}

In eddy-covariance measurements, as noted in Sect. 3.1 above, GPP and ER are obtained by partitioning the observed NEP on the basis of empirically derived relationships. In the case of modelled carbon fluxes, on the other hand, NEP is calculated by subtracting ER from GPP, therefore the error in the NEP simulations accumulates the errors in GPP and ER. Bearing in mind these caveats, examination of the modelled daily GPP, ER, and NEP suggests that the model is capable of capturing seasonal dynamics and climate-driven events consistently in various types of peatlands. Figures $8-10$ show the daily average fluxes in time series form. The RMSE (Table 6) is between 0.43 and $0.67 \mathrm{~g} \mathrm{C} \mathrm{m}^{-2}$ day $^{-1}$ for GPP and ER for the three sites in Scandinavia and Canada (FI-Kaa, MB-Bog, and SE-Faj, two bogs and a fen) that have high-quality observed data and are not undergoing vegetation shifts. Larger biases of GPP and ER occurred in the blanket bog (UK-Amo) and the Russian ombrotrophic bog (RU-Fyo), the peat depths of which were very deep and relatively shallow respectively 
Table 5. Summary of statistics of model performance with respect to daily average latent heat flux (QH), sensible heat flux (QE), and soil $T$ at $5 \mathrm{~cm}\left(T_{\mathrm{s} 5}\right) .{ }^{*}$ Indicates unrealistic values observed for the site.

\begin{tabular}{|c|c|c|c|c|c|c|c|c|c|c|}
\hline & \multirow[t]{2}{*}{ Site } & \multicolumn{4}{|c|}{ Bog } & \multicolumn{4}{|c|}{ Fen } & \multirow{2}{*}{ Mean } \\
\hline & & $\begin{array}{l}\text { MB- } \\
\text { Bog }\end{array}$ & $\begin{array}{l}\text { SE- } \\
\text { Faj }\end{array}$ & $\begin{array}{l}\text { RU- } \\
\text { Fyo }\end{array}$ & $\begin{array}{l}\text { UK- } \\
\text { Amo }\end{array}$ & $\begin{array}{l}\text { AB- } \\
\text { Fen }\end{array}$ & $\begin{array}{l}\text { FI- } \\
\text { Kaa }\end{array}$ & $\begin{array}{l}\text { FI- } \\
\text { Lom }\end{array}$ & $\begin{array}{l}\text { SE- } \\
\text { Deg }\end{array}$ & \\
\hline \multirow{2}{*}{$\mathrm{QH}\left(\mathrm{W} \mathrm{m}^{-2}\right)$} & $r^{2}$ & 0.65 & 0.50 & 0.41 & 0.22 & 0.89 & 0.25 & 0.42 & 0.39 & 0.47 \\
\hline & RMSE & 23.0 & 27.3 & 37.7 & 31.0 & 41.5 & 36.7 & 25.4 & 19.6 & 30.3 \\
\hline \multirow[t]{2}{*}{$\mathrm{QE}\left(\mathrm{W} \mathrm{m}^{-2}\right)$} & $r^{2}$ & 0.89 & 0.56 & 0.51 & $0.01^{*}$ & 0.82 & 0.35 & 0.49 & 0.54 & 0.52 \\
\hline & RMSE & 27.3 & 33.5 & 33.3 & 79.7 & 15.8 & 31.5 & 28.3 & 23.9 & 34.1 \\
\hline \multirow[t]{2}{*}{$T_{\mathrm{s} 5}\left({ }^{\circ} \mathrm{C}\right)$} & $r^{2}$ & 0.98 & 0.87 & 0.88 & 0.77 & 0.91 & 0.85 & 0.90 & 0.79 & 0.87 \\
\hline & RMSE & 1.7 & 2.6 & 4.6 & 2.3 & 4.7 & 2.9 & 2.1 & 3.86 & 3.1 \\
\hline
\end{tabular}

Table 6. Summary of statistics of model performance with respect to GPP, ER, and NEP ( $\left.\mathrm{g} \mathrm{C} \mathrm{m}^{-2} \mathrm{day}^{-1}\right)$.

\begin{tabular}{|c|c|c|c|c|c|c|c|c|c|c|}
\hline & \multirow[t]{2}{*}{ Site } & \multicolumn{4}{|c|}{ Bog } & \multicolumn{4}{|c|}{ Fen } & \multirow[t]{2}{*}{ Mean } \\
\hline & & $\begin{array}{c}\text { MB- } \\
\text { Bog }\end{array}$ & $\begin{array}{l}\text { SE- } \\
\text { Faj }\end{array}$ & $\begin{array}{l}\text { RU- } \\
\text { Fyo }\end{array}$ & $\begin{array}{l}\text { UK- } \\
\text { Amo }\end{array}$ & $\begin{array}{l}\text { AB- } \\
\text { Fen }\end{array}$ & $\begin{array}{l}\text { FI- } \\
\text { Kaa }\end{array}$ & $\begin{array}{l}\text { FI- } \\
\text { Lom }\end{array}$ & $\begin{array}{l}\text { SE- } \\
\text { Deg }\end{array}$ & \\
\hline \multirow{2}{*}{ Daily GPP $\left(\mathrm{gC} \mathrm{m}^{-2} \mathrm{~d}^{-1}\right)$} & $r^{2}$ & 0.90 & 0.80 & 0.81 & 0.63 & 0.95 & 0.78 & 0.76 & 0.65 & 0.79 \\
\hline & RMSE & 0.669 & 0.606 & 2.36 & 1.44 & 1.45 & 0.601 & 1.07 & 0.84 & 1.13 \\
\hline \multirow[t]{2}{*}{ Daily ER $\left(\mathrm{gC} \mathrm{m}^{-2} \mathrm{~d}^{-1}\right)$} & $r^{2}$ & 0.91 & 0.84 & 0.61 & 0.56 & 0.93 & 0.73 & 0.80 & 0.54 & 0.74 \\
\hline & RMSE & 0.524 & 0.456 & 2.90 & 1.12 & 0.867 & 0.431 & 0.543 & 0.615 & 0.93 \\
\hline \multirow[t]{2}{*}{ Daily NEP $\left(\mathrm{gC} \mathrm{m}^{-2} \mathrm{~d}^{-1}\right)$} & $r^{2}$ & 0.45 & 0.21 & 0.30 & 0.17 & 0.72 & 0.28 & 0.35 & 0.41 & 0.36 \\
\hline & RMSE & 0.724 & 0.539 & 1.65 & 0.936 & 1.01 & 0.624 & 1.00 & 0.486 & 0.87 \\
\hline
\end{tabular}

- up to $10 \mathrm{~m}$ in UK-Amo and $1 \mathrm{~m}$ in RU-Fyo (Table 4). Variations in the historical climate have led to variations in the peat accumulation rates over the Holocene and the vertical stratification of the peat and hence the decomposition rates and decomposability of the peat, which become important for deeper, older peat deposits. The Russian bog may be an outlier because warm climate conditions persisted until about 5000 BP in northern Siberia and about 1000 years later in most other areas (Yu et al., 2010). The RU-Fyo bog experienced a period of low GPP due to an abrupt decrease of air temperature in the early fall of 2010 , which was well reproduced by the model. The starting and ending periods of photosynthesis in the spring and fall were accurately simulated except for the coldest peatland, FI-Lom, where the length of the growing season was slightly overestimated. Short periods of overestimation of soil temperature at $5 \mathrm{~cm}$ existed during that period, by up to $5^{\circ} \mathrm{C}$, which may have caused the errors in GPP; Moore et al. (2006) noted a high correlation between soil temperature and the initiation of photosynthesis in the spring.

The RMSE of the daily NEP simulations (Table 6) ranges from 0.486 to $1.65 \mathrm{~g} \mathrm{C} \mathrm{m}^{-2} \mathrm{day}^{-1}$. The lowest biases were for the SE-Faj bog and the two poor fens (SE-Deg and FIKaa) that had little vegetation cover, with the maximum LAI below $1.0 \mathrm{~m}^{2} \mathrm{~m}^{-2}$. Values of $\mathrm{r}^{2}$ greater than about 0.3 were observed at six sites. At the other two, SE-Faj and UKAmo, the observed NEP varied widely, ranging from -1.8 to $2.2 \mathrm{~g} \mathrm{C} \mathrm{m}^{-2}$ day ${ }^{-1}$ and from -3.9 to $4.8 \mathrm{~g} \mathrm{C} \mathrm{m}^{-2}$ day $^{-1}$ respectively. The discrepancy with the modelled values, contributing to the low $r^{2}$ values for these two sites, might be due either to weaknesses in the model or to inadequate screening of the eddy covariance measurements. NEP was overestimated at the beginning and the end of the growing season for FI-Lom due to the overestimation of GPP for that period as discussed above. These results may be compared to an evaluation of the MWM using the SE-Deg data set that was conducted by Wu et al. (2013). For daily NEP they obtained an RMSE of 0.49 , similar to ours, but a higher $r^{2}$ of 0.52 . It should be noted that the MWM was driven by observed WTD and soil temperature, while in our simulations these were allowed to evolve freely, so our comparable result is gratifying.

Figures 11-13 show the daily modelled vs. observed GPP, ER and NEP in scatter plot form. Although the model performs reasonably well, with $r^{2}$ values averaging over 0.7 for both GPP and ER, a general tendency can be seen for the modelled GPP to be biased low at high and low values, and high at medium values. The bias in the very low values may be spurious, given the relatively large errors associated with eddy covariance measurements of small fluxes; also, the oc- 

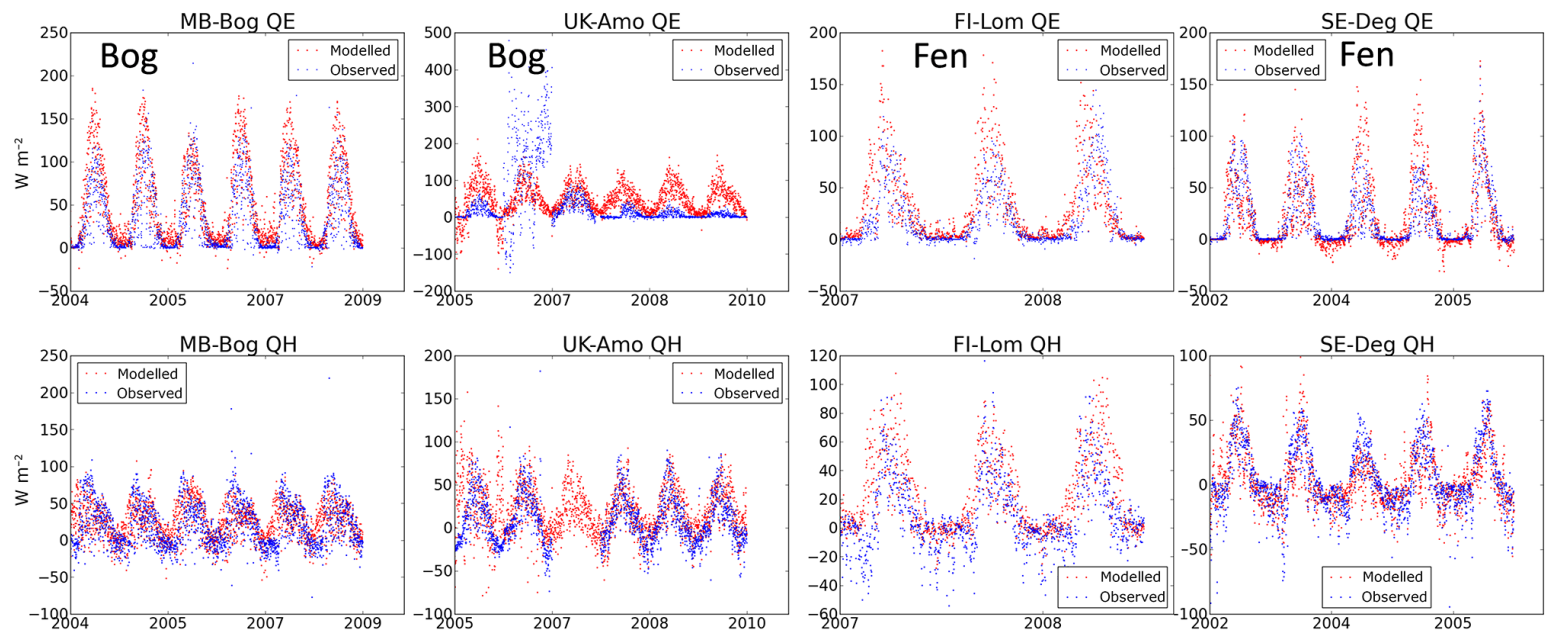

Figure 6. Simulated and observed daily average latent heat flux $\mathrm{QE}\left(\mathrm{W} \mathrm{m}^{-2}\right)$ and sensible heat flux $\mathrm{QH}\left(\mathrm{W} \mathrm{m}{ }^{-2}\right)$ in two bogs $(\mathrm{MB}-\mathrm{Bog}$ and UK-Amo) and two fens (FI-Lom and SE-Deg).
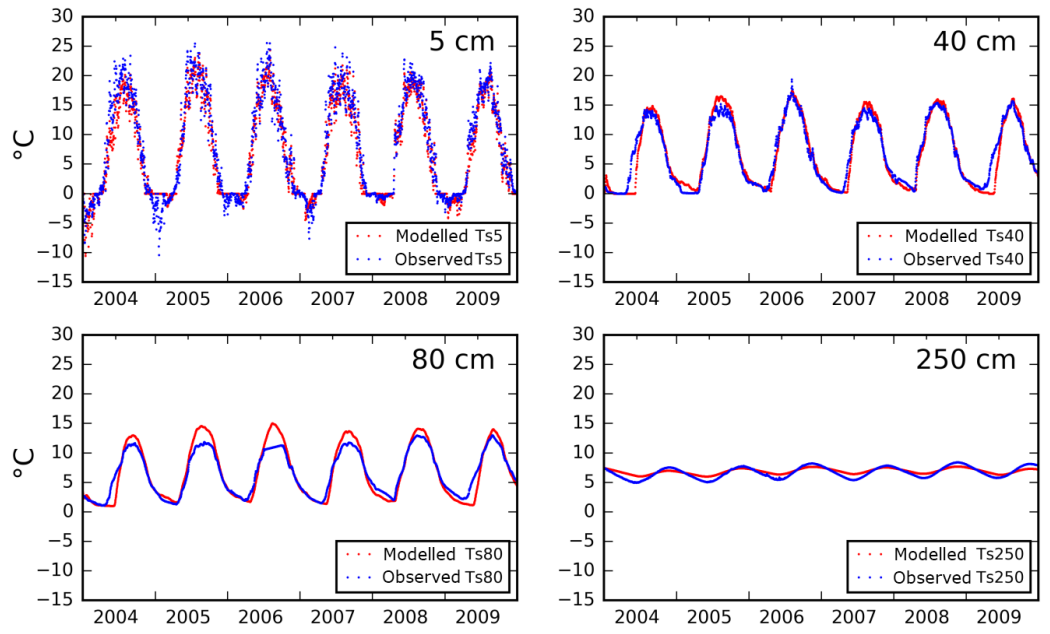

Figure 7. Simulated and observed daily mean soil temperature $T_{\mathrm{S}}\left({ }^{\circ} \mathrm{C}\right)$ at $5,40,80$, and $250 \mathrm{~cm}$ at the Mer Bleue bog. Note that the simulated temperatures at 40 and $80 \mathrm{~cm}$ are interpolated from the simulated soil layer temperatures above and below these depths. The deepest measurement corresponds approximately to the midpoint of the lowest soil layer.

casional negative observed values of GPP may be indicative of erroneous partitioning of the measured NEP between GPP and ER. At FI-Lom, FI-Kaa, and UK-Amo, the high model bias at low observed values may be related to early leaf-out and/or delayed leaf drop. The biases at medium values are possibly related to the use of the "big-leaf" assumption in CLASS-CTEM, which neglects sunlit and shaded canopy fractional areas, and may have a dampening effect on photosynthesis. Low biases at high values may be related to water stress caused by a low water table, as seen in Fig. 4 for RUFyo and FI-Lom. In the case of ER, the modelled values do not show systematic biases except for RU-Fyo and UK-Amo, which were difficult to model as noted above. Given the fact that a major focus of this study was the incorporation of res- piration for organic soils and mosses into CLASS-CTEM, this is encouraging.

Since NEP is the residual of two large terms, GPP and ER, in Fig. 14 we investigate the relationship between the modelled GPP, autotrophic respiration (AR) and HR. Across most sites, simulated AR is approximately $40-50 \%$ of GPP with a relatively consistent relationship between the two. In CLASS-CTEM, autotrophic respiration is sensitive to temperature, the maximum catalytic capacity of Rubsico, and the vertical profile of radiation along the depth of the canopy (Melton and Arora, 2016). GPP is also sensitive to these same factors and thus tends to respond similarly. HR is much more variable than AR and GPP and also shows greater variability between sites. FI-Kaa is relatively consistent in sim- 

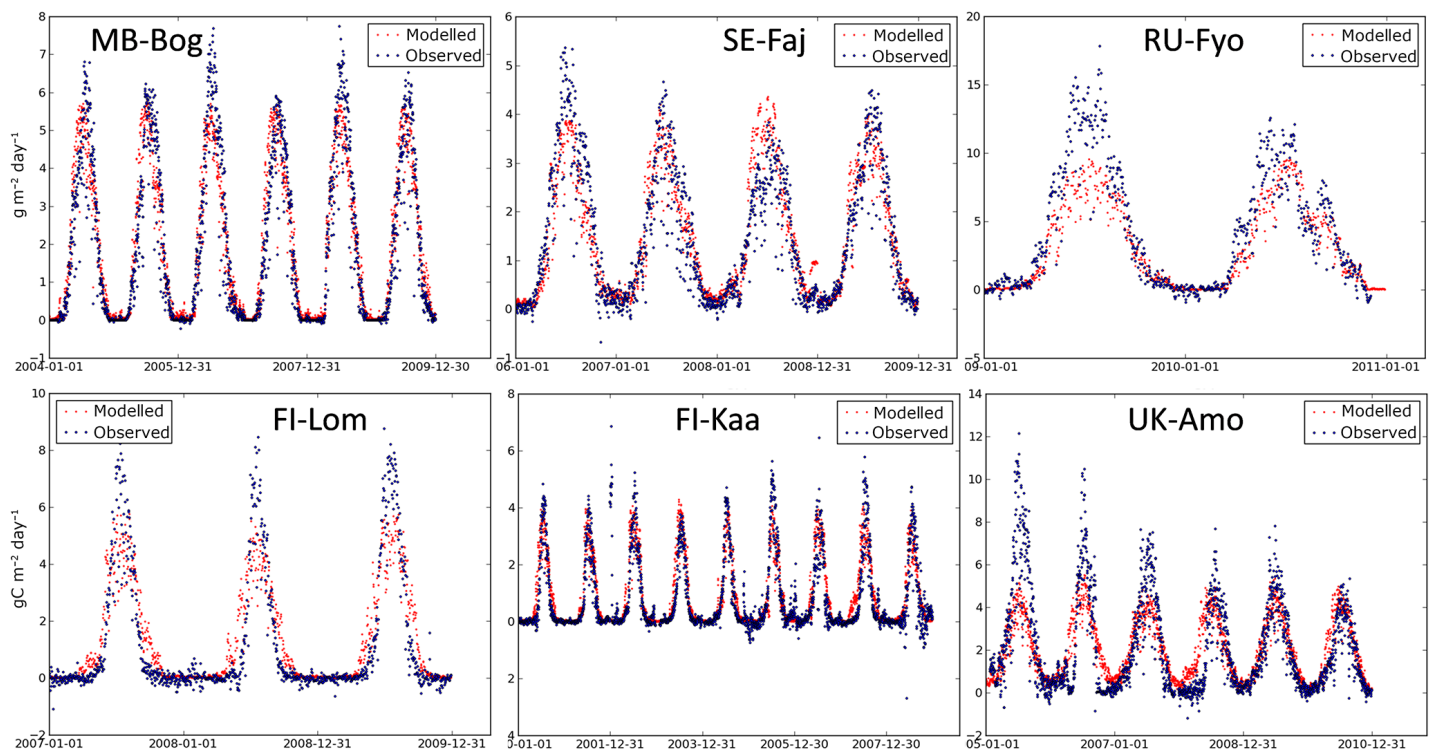

Figure 8. Simulated and observed daily GPP $\left(\mathrm{gC} \mathrm{m}^{-2} \mathrm{day}^{-1}\right)$ in bogs and fens.
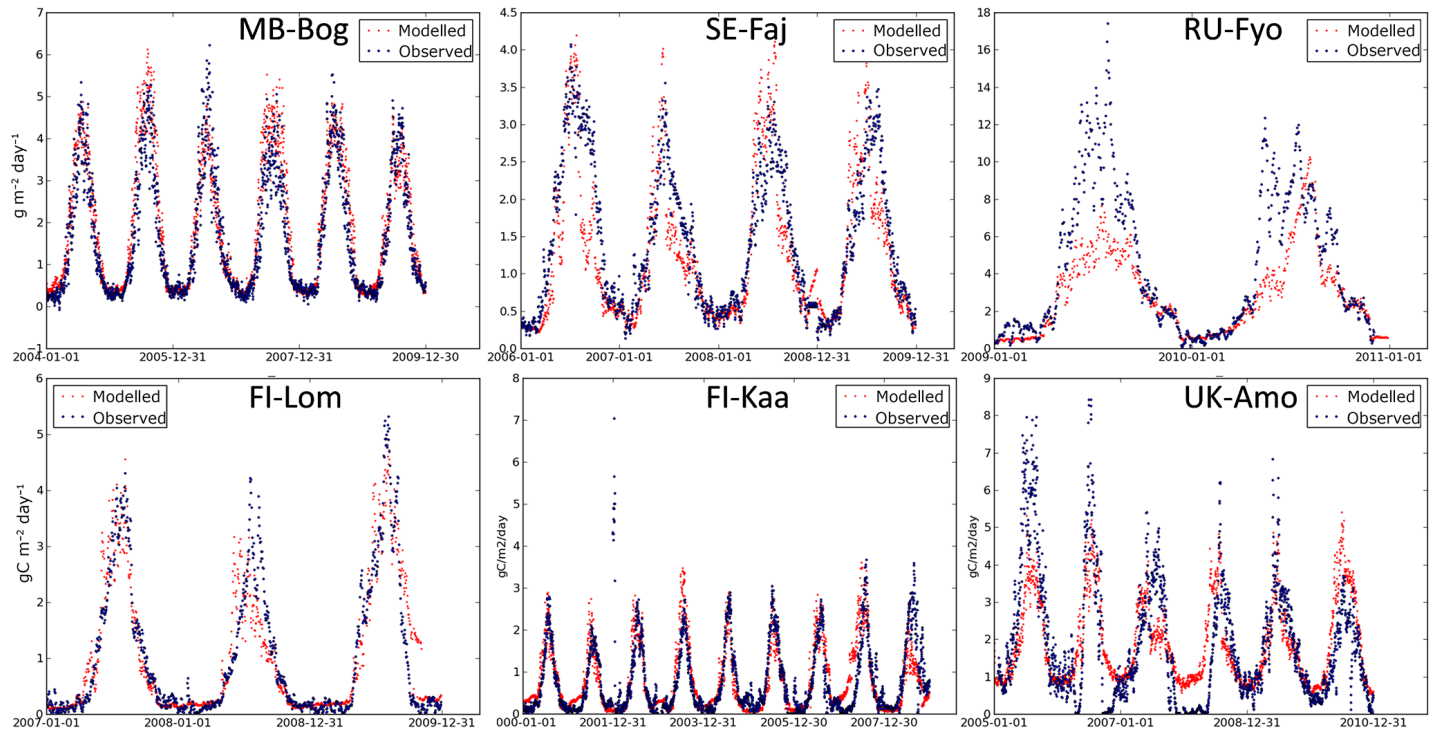

Figure 9. Simulated and observed daily ER $\left(\mathrm{gC} \mathrm{m}^{-2}\right.$ day $\left.^{-1}\right)$ in bogs and fens.

ulated HR, whereas sites such as SE-Faj and FI-Lom have markedly variable HR fluxes. HR in CLASS-CTEM is sensitive to soil matric potential, soil temperature and detrital carbon stocks (Melton and Arora, 2016). The strongest control on the HR variability at these sites appears to be the soil matric potential. The CLASS-CTEM HR parameterization has a maximal rate at a soil matric potential intermediate between wet and dry soils (absolute soil matric potential between 0.04 and $0.06 \mathrm{MPa}$; see Fig. 1 in Melton et al., 2015). The primary assumption of the HR parameterization is that soil moisture constrains HR when soils are very dry due to limited microbial respiration. As soil become very wet, HR also drops to reflect diminished oxygen supply to microbes. The sites with the high variability of HR tend to reflect soil moisture conditions during the growing season with soil matric potentials fluctuating between the zone of optimal HR production and shutdown due to overly moist soils. For example, in 2007, SE-Faj had high variability of HR with the water table rising from $12 \mathrm{~cm}$ to only a few centimetres below the soil surface (indicating saturated soil conditions) resulting in a large shutdown of the HR flux, while 2008 was a drier year with a water table more consistently about $20 \mathrm{~cm}$ below the surface and much less variable HR fluxes simulated. 

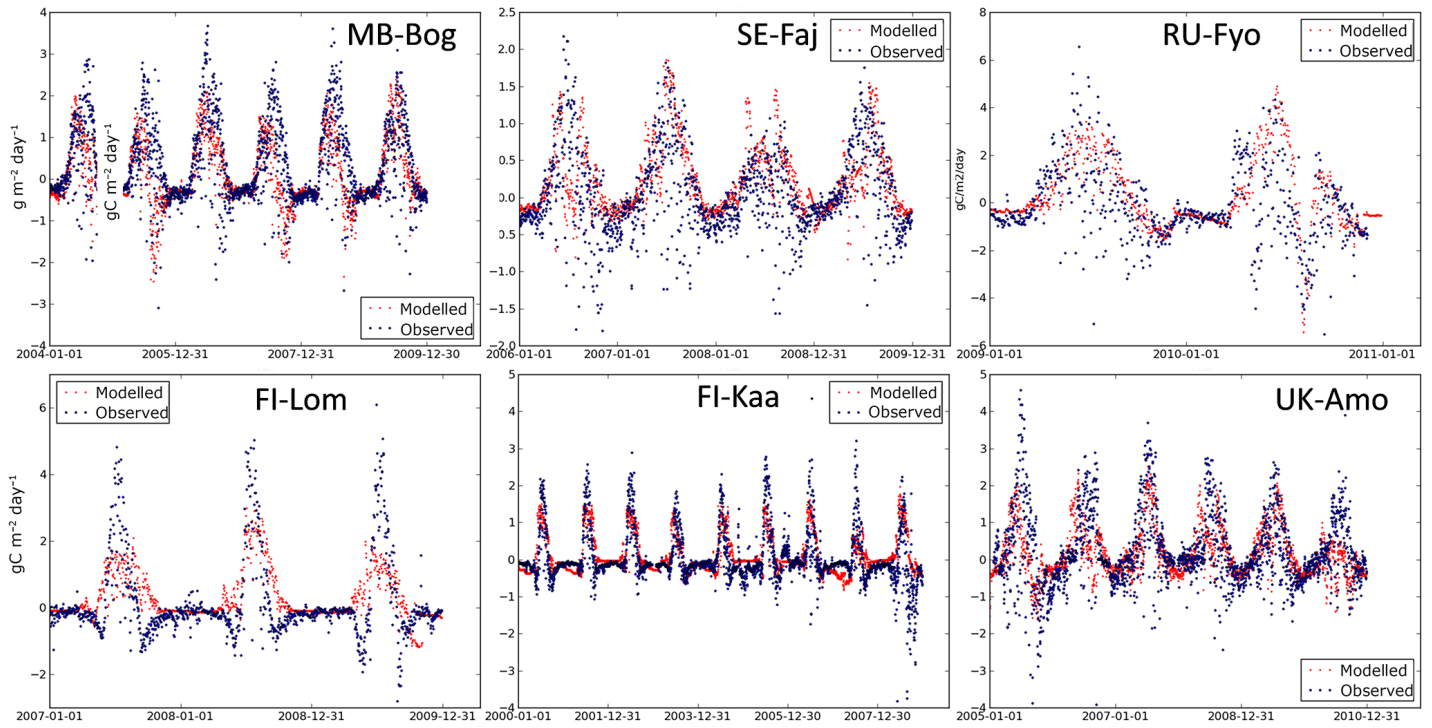

Figure 10. Simulated and observed daily NEP $\left(\mathrm{gC} \mathrm{m}^{-2} \mathrm{day}^{-1}\right)$ in bogs and fens.
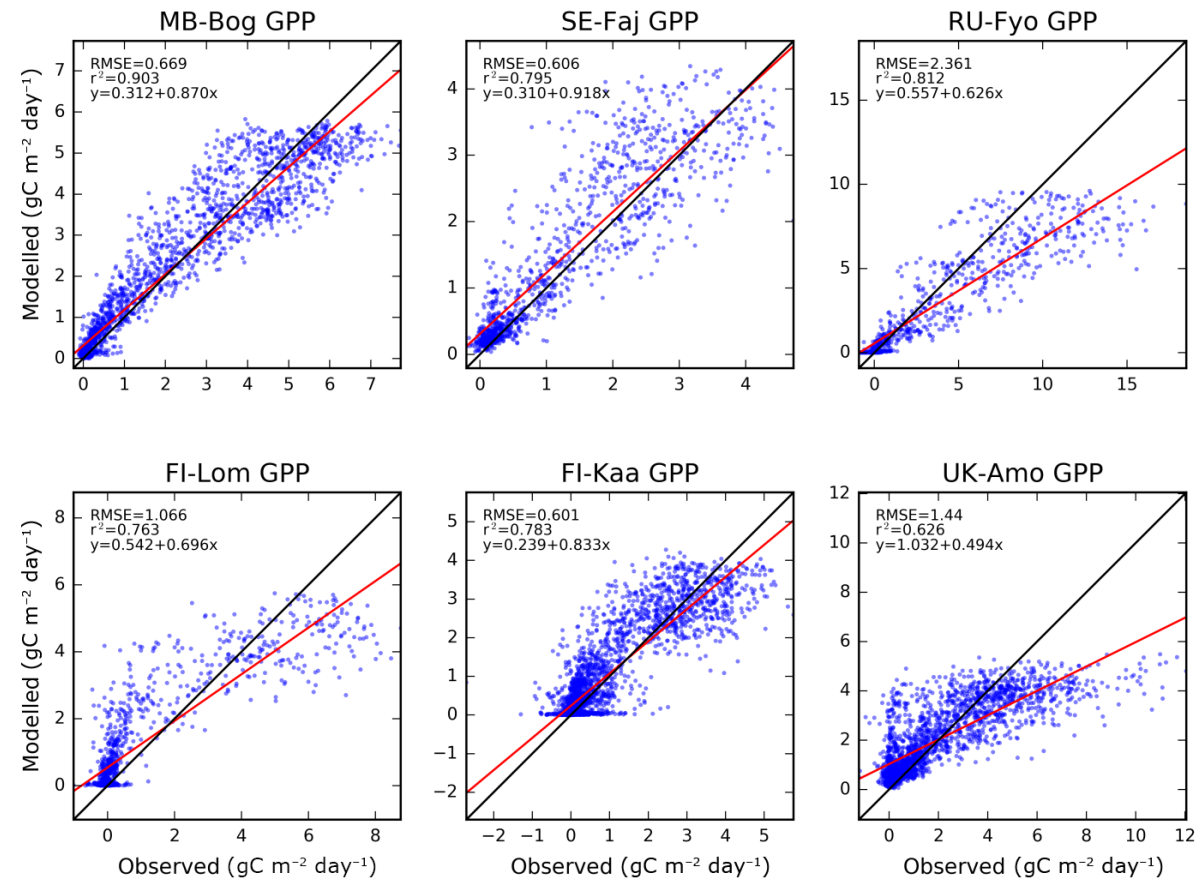

Figure 11. Scatter plots of simulated vs. observed daily GPP $\left(\mathrm{gC} \mathrm{m}^{-2} \mathrm{day}^{-1}\right)$ in bogs and fens.

The simulated accumulated monthly NEP from March to November agreed well with the observations in the four bogs and four fens. The outliers for bogs were the overestimations in MB-Bog in October and November due to the underestimation of GPP (Fig. 8). The NEP in RU-Fyo in one August was underestimated owing to the underestimated GPP, which in turn was a result of the underestimated LAI and rooting depth temperature in the summer. Figure 15, showing plots of NEP averaged for each month of the year at each site, demonstrates on the whole larger scatter for the bogs than the fens, with the scatter increasing through the summer and fall. The overall value of $r^{2}$ was 0.59 for bogs and 0.58 for fens; both values are higher than or similar to those obtained in evaluations of other peatland $\mathrm{C}$ models. For example, the $r^{2}$ value of the monthly NEP for LPJ-WHy was reported to be 0.35 for four peatlands, with three of the sites overlapping those used in this study: SE-Deg, FI-Kaa, and MB-Bog (Wania et al., 2009b). The Finland peatland model simulated 

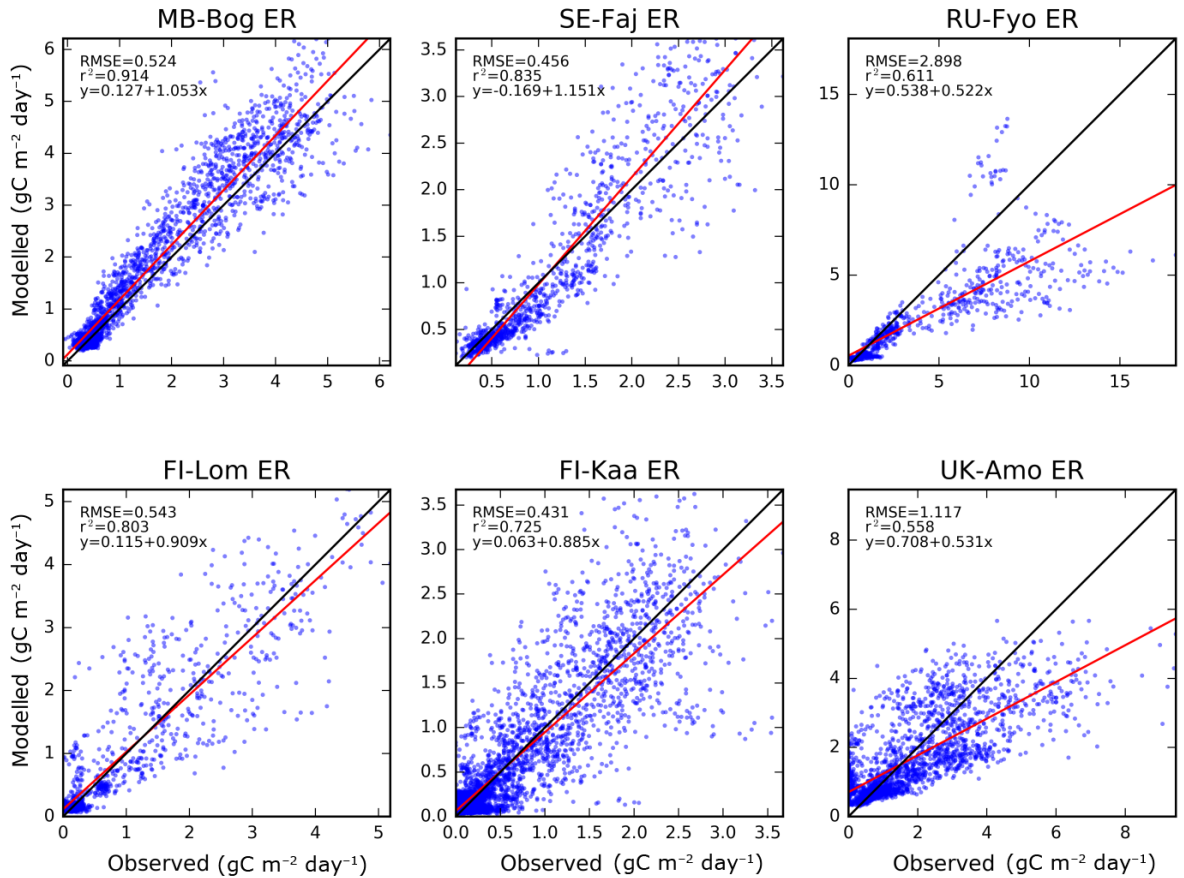

Figure 12. Scatter plots of simulated vs. observed daily ER $\left(\mathrm{gC} \mathrm{m}^{-2} \mathrm{day}^{-1}\right)$ in bogs and fens.
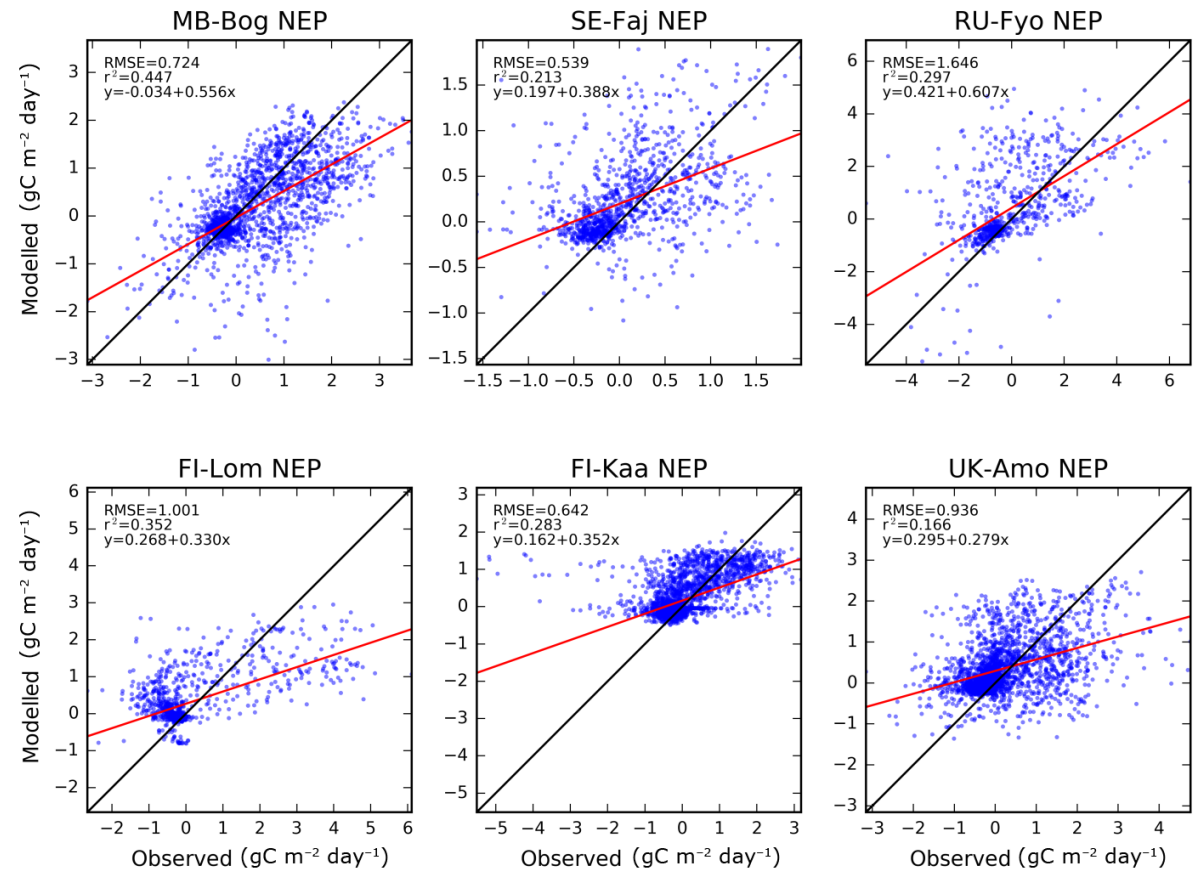

Figure 13. Scatter plots of simulated vs. observed daily NEP $\left(\mathrm{gC} \mathrm{m}^{-2} \mathrm{day}^{-1}\right)$ in bogs and fens.

the NEP in FI-Kaa with $r^{2}$ of 0.80 for the same time period tested for our model (Gong et al., 2013), but only the one site was used in the evaluation.

\subsection{Annual net ecosystem production}

The simulated mean annual NEP values with their standard deviations generally fall within the range of the standard deviations of the observations (Fig. 16), between $9 \mathrm{~g} \mathrm{C} \mathrm{m}^{-2} \mathrm{yr}^{-1}$ in the rich fen (FI-Lom) and $73 \mathrm{~g} \mathrm{C} \mathrm{m}^{-2} \mathrm{yr}^{-1}$ 

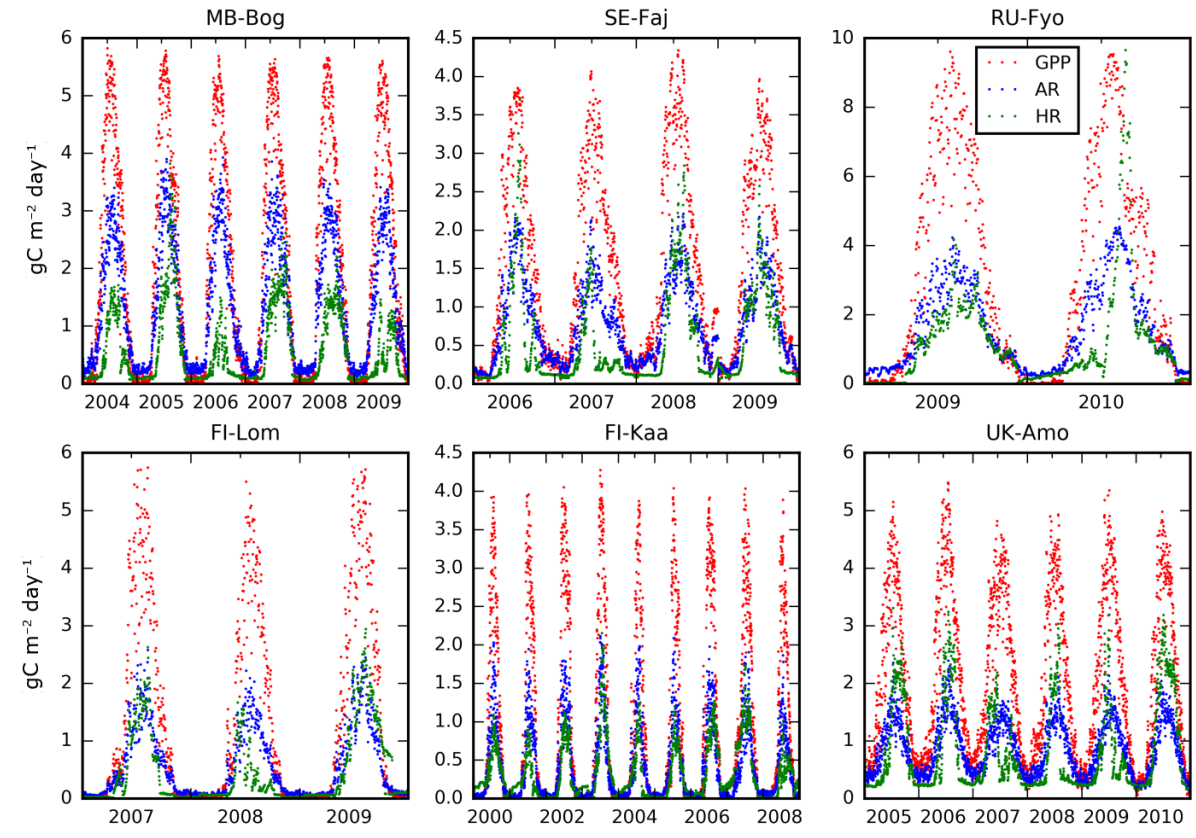

Figure 14. Simulated GPP, autotrophic respiration (AR) and heterotrophic respiration (HR) $\left(\mathrm{gC} \mathrm{m}^{-2} \mathrm{~d}^{-1}\right)$ for bogs and fens.
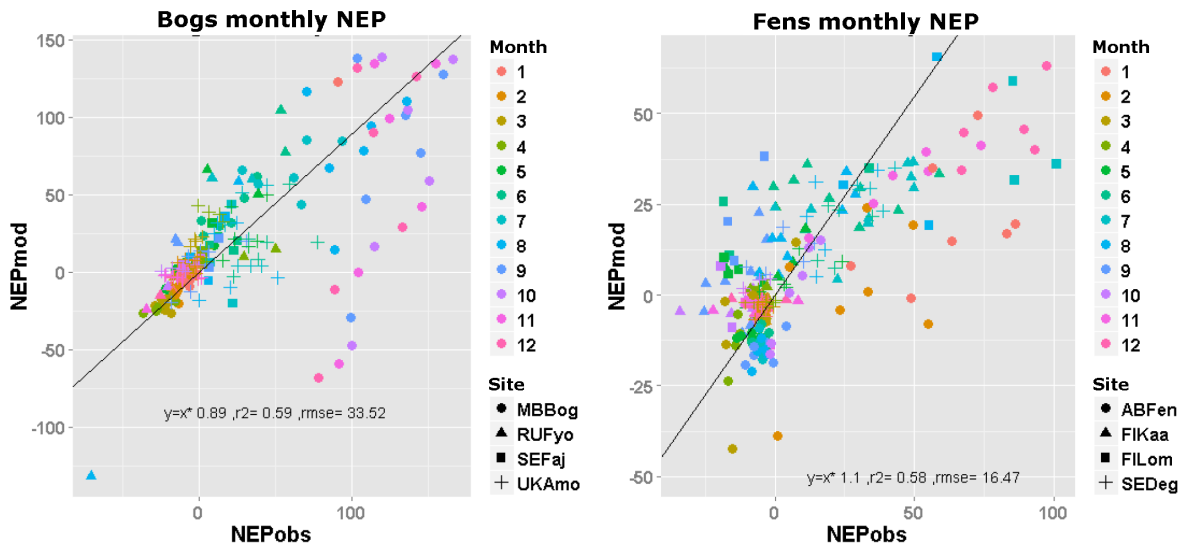

Figure 15. Scatter plots of simulated and observed monthly mean NEP $\left(\mathrm{gC} \mathrm{m}^{-2} \mathrm{month}^{-1}\right)$ in bogs and fens. The sites are represented by different symbols and NEP for each of the 12 months is colour-coded. The black line represents the best fit of the modelled NEP and the observed NEP.

in the productive bog (RU-Fyo) (Table 7). The only site with a large bias in annual NEP was AB-Fen. Observation-based estimations of NEP in this fen were extremely high, totalling $176 \mathrm{~g} \mathrm{C}$ from May to October, in comparison with other sites (Syed et al., 2006). This treed fen had a high peat density and LAI and large variation in the WTD, which, accompanied by high spring temperatures, resulted in high ecosystem photosynthesis capacity and production (Adkinson et al., 2011). Considering nutrient factors and the site-specific peat density could potentially capture the large NEP at this site. The observed annual NEP for the eight sites varied greatly overall, between -17 and $187 \mathrm{gC} \mathrm{m}^{-2} \mathrm{yr}^{-1}$, while the simulated NEP showed slightly less variation, ranging from
13 to $157 \mathrm{~g} \mathrm{C} \mathrm{m}^{-2} \mathrm{yr}^{-1}$. The simulated mean annual NEP across the sites was $87 \mathrm{~g} \mathrm{C} \mathrm{m}^{-2} \mathrm{yr}^{-1}$ and was $22 \mathrm{~g} \mathrm{C} \mathrm{m}^{-2}$ $\mathrm{yr}^{-1}$ higher than the mean observed NEP. In contrast the LPJ-WHy model simulated most of the annual NEP between -5 to $0 \mathrm{~g} \mathrm{C} \mathrm{m}^{-2} \mathrm{yr}^{-1}$, lower than their observed median of $40 \mathrm{~g} \mathrm{C} \mathrm{m}^{-2} \mathrm{yr}^{-1}$ (Wania et al., 2009b). As noted above, variations in the depth and age of the peat at the eight sites reflected fluctuations in past climate, leading to site-specific soil properties that were not always captured by the standardized values used in the model. Peatlands in different geographical locations also reflected the effects of local conditions: for example, the blanket bog UK-Amo in a maritime climate accumulated $101 \mathrm{~g} \mathrm{C} \mathrm{m}^{-2} \mathrm{yr}^{-1}$ in 2007 (Dinsmore et 
Table 7. Summary of observed (obs.) and modelled (mod.) mean annual GPP, ER, and NEP of the eight sites with standard deviation shown in brackets; units are $\mathrm{g} \mathrm{C} \mathrm{m}^{-2} \mathrm{yr}^{-1}$.

\begin{tabular}{|c|c|c|c|c|c|c|c|c|c|}
\hline \multirow[t]{2}{*}{ Site } & \multicolumn{4}{|c|}{ Bog } & \multicolumn{4}{|c|}{ Fen } & \multirow[t]{2}{*}{ Mean } \\
\hline & $\begin{array}{l}\text { MB- } \\
\text { Bog }\end{array}$ & $\begin{array}{l}\text { SE- } \\
\text { Faj }\end{array}$ & $\begin{array}{l}\text { RU- } \\
\text { Fyo }\end{array}$ & $\begin{array}{l}\text { UK- } \\
\text { Amo }\end{array}$ & $\begin{array}{l}\text { AB- } \\
\text { Fen }\end{array}$ & $\begin{array}{l}\text { FI- } \\
\text { Kaa }\end{array}$ & $\begin{array}{l}\text { FI- } \\
\text { Lom }\end{array}$ & $\begin{array}{l}\text { SE- } \\
\text { Deg }\end{array}$ & \\
\hline GPP obs. & $714( \pm 45)$ & $472( \pm 3)$ & $1502( \pm 251)$ & $789( \pm 189)$ & $864( \pm 172)$ & $289( \pm 39)$ & $418( \pm 52)$ & $383( \pm 24)$ & 679 \\
\hline GPP mod. & $734( \pm 15)$ & $573( \pm 49)$ & $1135( \pm 4)$ & $752( \pm 37)$ & $594( \pm 72)$ & $327( \pm 33)$ & $489( \pm 39)$ & $300( \pm 71)$ & 613 \\
\hline ER obs. & $612( \pm 29)$ & $536( \pm 102)$ & $1545( \pm 119)$ & $706( \pm 212)$ & $678( \pm 160)$ & $270( \pm 40)$ & $380( \pm 59)$ & $295( \pm 36)$ & 628 \\
\hline ER mod. & $690( \pm 89)$ & $426( \pm 55)$ & $1000( \pm 86)$ & $594( \pm 46)$ & $581( \pm 88)$ & $270( \pm 46)$ & $372( \pm 96)$ & $224( \pm 76)$ & 520 \\
\hline NEP obs. & $103( \pm 25)$ & $25( \pm 34)$ & $-17( \pm 73)$ & $87( \pm 48)$ & $187( \pm 37)$ & $17( \pm 29)$ & $57( \pm 9)$ & $58( \pm 6)$ & 65 \\
\hline NEP mod. & $44( \pm 78)$ & $97( \pm 77)$ & $135( \pm 91)$ & $157( \pm 43)$ & $13(63)$ & $57( \pm 22)$ & $117( \pm 57)$ & $77( \pm 5)$ & 87 \\
\hline
\end{tabular}

al., 2010) while the dry MB-Bog was estimated to be a source of $13.8 \mathrm{~g} \mathrm{C} \mathrm{m}^{-2} \mathrm{yr}^{-1}$ (Roulet et al., 2007). The modelled NEP bias tended towards underestimation for the treed fen (AB-fen) and the productive ombrotrophic bog (MB-Bog), and towards overestimation for the remaining sites.

The model errors in GPP were smaller than the standard deviation of the observations, except for the atypical sites (AB-Fen, RU-Fyo) and the sites that had only a few years of data (FI-Lom, SE-Faj) (Table 7). The bias of the simulated ER did not exceed the error bars except for in the RU-Fyo bog, for which a thin peat depth of $1 \mathrm{~m}$ was used to initialize the simulation (Table 4). The simulated WTD was consistently shallower in the summer than the observations (Fig. 4), which slowed down the soil respiration in the model and contributed to the discrepancies in ER. The observed WTD showed an abrupt decrease in the summer of 2010 without pulses of large ER being observed during that period (Fig. 9), indicating uncertainties in the WTD observations. Another reason for the errors in ER was the underestimation in soil $T$. For example, the simulated soil $T$ at $5 \mathrm{~cm}$ depth was higher in the summers with RMSE of $4.6^{\circ} \mathrm{C}$ in RU-Fyo (Table 5). The site is particularly shallow and homogeneous; thus, the standardized living moss layer of $4 \mathrm{~cm}$ for bogs was probably too large, leading to an overestimation of the thermal insulation effect from the moss layers and hence less seasonal variation in soil temperature and ER.

An overview of the model's performance is illustrated via a series of Taylor diagrams (Fig. 17). Taylor diagrams provide a graphical summary of how closely modelled data match observed data (Taylor, 2001). The radial spokes represent the level of correlation and the $x$ and $y$ axes show the standard deviation. The standard deviation of the observations is plotted on the $x$ axis, and the RMSE of the modelled values is indicated by the concentric contours around this point. Since we have eight pairs of modelled and observed points for each diagram, we normalized the data by dividing each of the standard deviations and the RMSEs by the standard deviation of the observations associated with each point, so that all the observation points fall at 1 on the $x$ axis. The outliers are the vegetated treed fen (AB-Fen), the maritime blanket bog UK-Amo and the extremely shallow peatland
RU-Fyo. The model simulations consistently agreed quite well with the observations except at these sites for some evaluated parameters. The Pearson $r$ was above 0.90 for the soil temperature at $5 \mathrm{~cm}$ and above 0.50 and 0.60 for the sensible and latent heat fluxes, except for those at UK-Amo. The modelled daily GPP and ER were highly correlated with the observations, with Pearson $r$ values between 0.80 and 0.95 for GPP, and between 0.70 and 0.96 for ER. The simulated daily NEP accumulated the errors in GPP and ER and was somewhat less well correlated with the observations, with Pearson $r$ values between 0.4 and 0.72 .

\subsection{The necessity of distinguishing fens and bogs}

The original version of our peatland model (referred to as "CONTROL" hereafter) as described above distinguishes bogs and fens through the controls of water table depth on soil decomposition and the depth of the living moss. The parameters for the water table depth regulation of soil decomposition were derived from the empirical relations in the MWM (Eqs. 13, 14). Our first test, " $K$-SWAP", involved swapping the values of the decomposition parameters (Table 3) between the bog and fen sites. As shown in Fig. 18, the differences between the test and control runs are generally very small. The relative differences in the simulated values of the fluxes and temperatures between $K-S W A P$ and $C O N$ TROL ranged from -1.6 to $+5.1 \%$ for RMSE and from -23 to $+6 \%$ for $r^{2}$. The relative differences in RMSE and $r^{2}$ for GPP, QH, QE, and $T_{\mathrm{s} 5}$ were smaller than $\pm 1 \%$. The largest differences in $r^{2}$ between $K$-SWAP and CONTROL were for NEP at SE-Faj and UK-Amo, which had significantly lower $r^{2}$ values than the other sites. The long-term effect on the overall carbon balance, as reflected in the cumulative NEP, is shown for six of the sites in Fig. 19. (AB-Fen and RU-Fyo are omitted, since the differences in those two cases were imperceptible for both sensitivity tests.) The cumulative differences were everywhere less than $15 \%$. The results of $K$ $S W A P$ indicate that parameterizing fens and bogs differently for the regulation of water table depth on soil decomposition does not make a large difference in the simulation. 

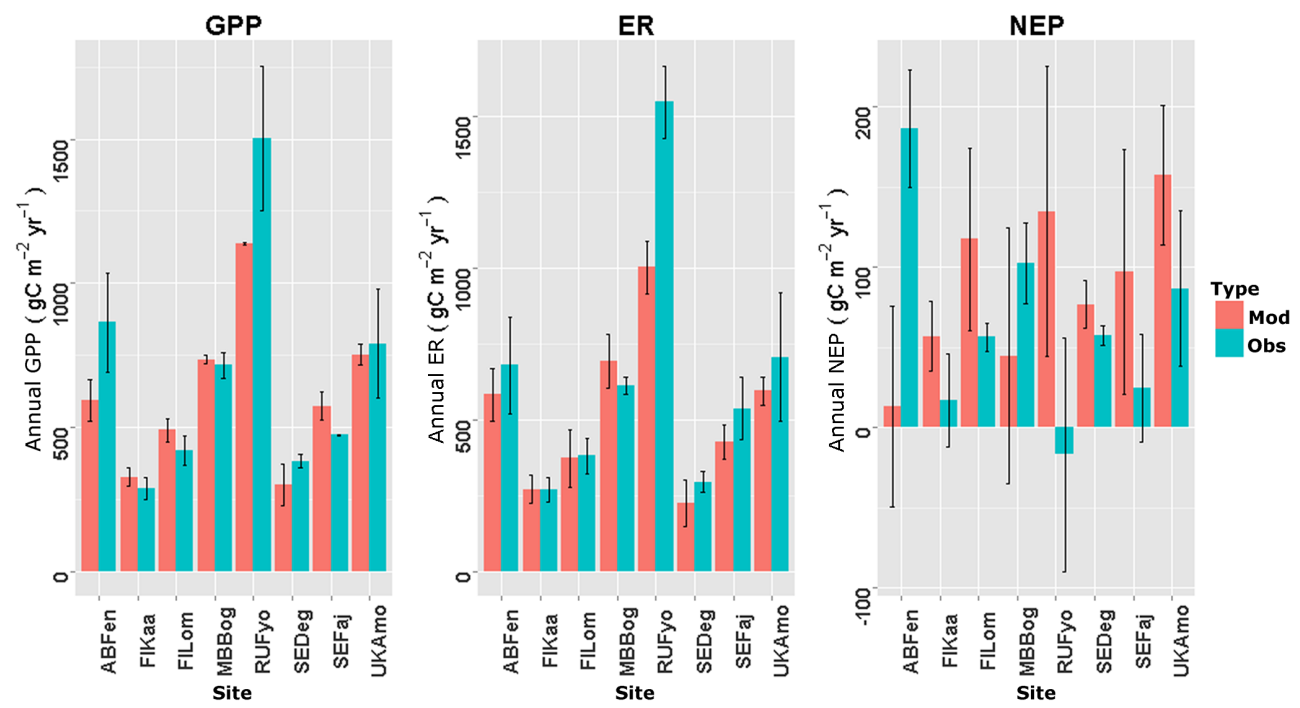

Figure 16. Observed and simulated annual GPP, ER, and NEP $\left(\mathrm{g} \mathrm{C} \mathrm{m}^{-2} \mathrm{yr}^{-1}\right)$ for the eight sites (error bars show the standard deviations); red bars are modelled fluxes and blue bars are observed fluxes.
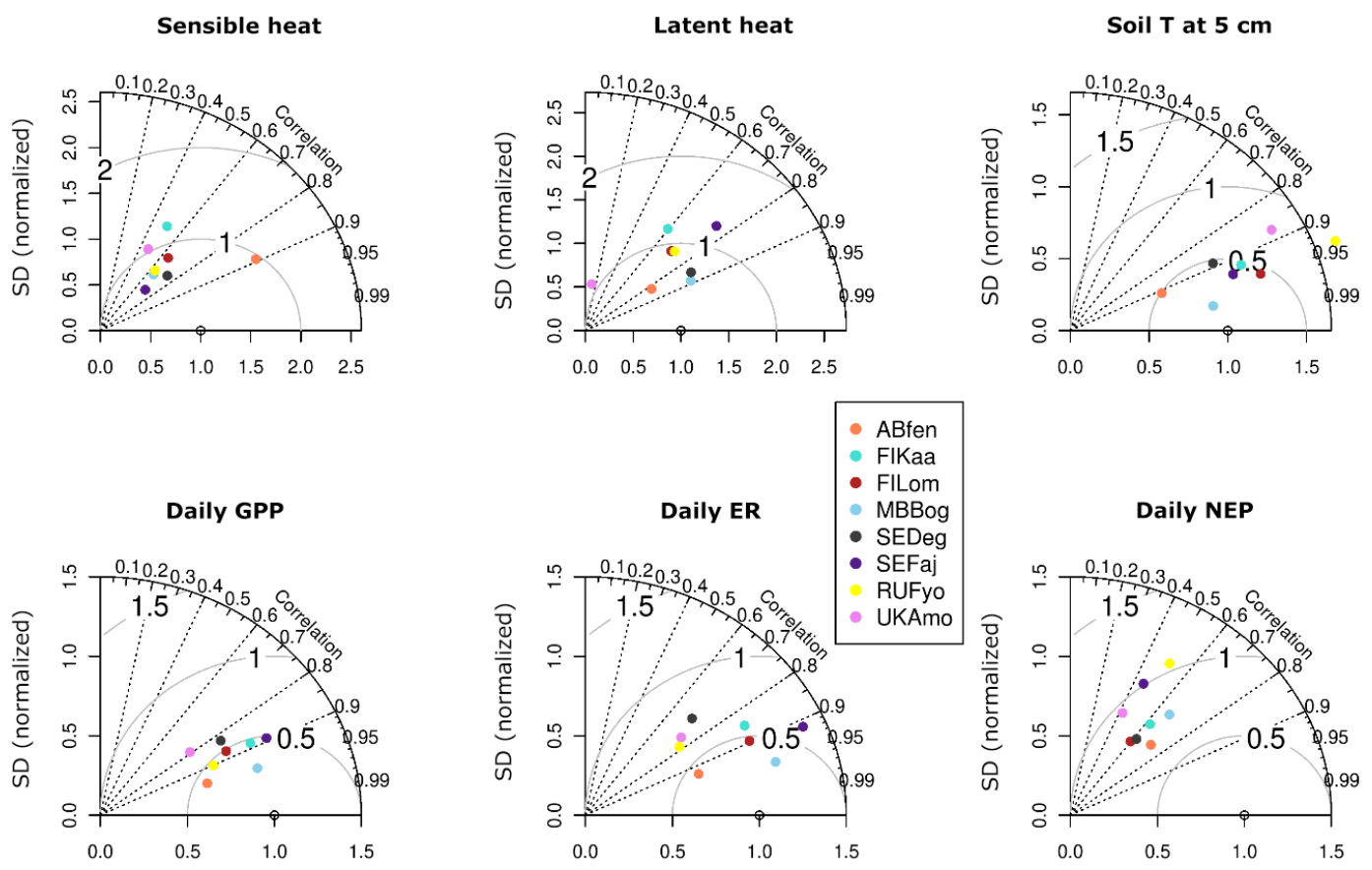

Figure 17. Taylor diagrams of model performance on average sensible heat flux $(\mathrm{QH})$, latent heat flux $(\mathrm{QE})$, soil temperature at $5 \mathrm{~cm}$ depth, and daily average GPP, ER, and NEP $\left(\mathrm{gC} \mathrm{m}^{-2} \mathrm{~d}^{-1}\right)$ in bogs and fens.

The second test, "D-MOSS", retained the settings in $K$ $S W A P$ and changed additionally the depth of the living moss in both bogs and fens to $3.5 \mathrm{~cm}$. The RMSE and $r^{2}$ of $D$ MOSS show site-specific differences compared to CONTROL (Fig. 18). The relative differences between D-MOSS and CONTROL in RMSE and $r^{2}$ were in the range of -5 to +7 and -15 to $+13 \%$ respectively. The mean differences for all sites and all evaluated variables were less than $5 \%$ for both
RMSE and $r^{2}$. For GPP, ER and the soil temperature at $5 \mathrm{~cm}$ depth, the $r^{2}$ in D-MOSS was similar to that of CONTROL. For QE, the $r^{2}$ in $D$-MOSS was higher than the control for all the fens and one unusual bog (UK-Amo), but not for the other three bogs. Compared to CONTROL, the $r^{2}$ of NEP was higher in D-MOSS for five sites by up to $7 \%$ and less than $2 \%$ lower in the other sites, except for UK-Amo where $r^{2}$ was also low in CONTROL. Turning to the long-term car- 

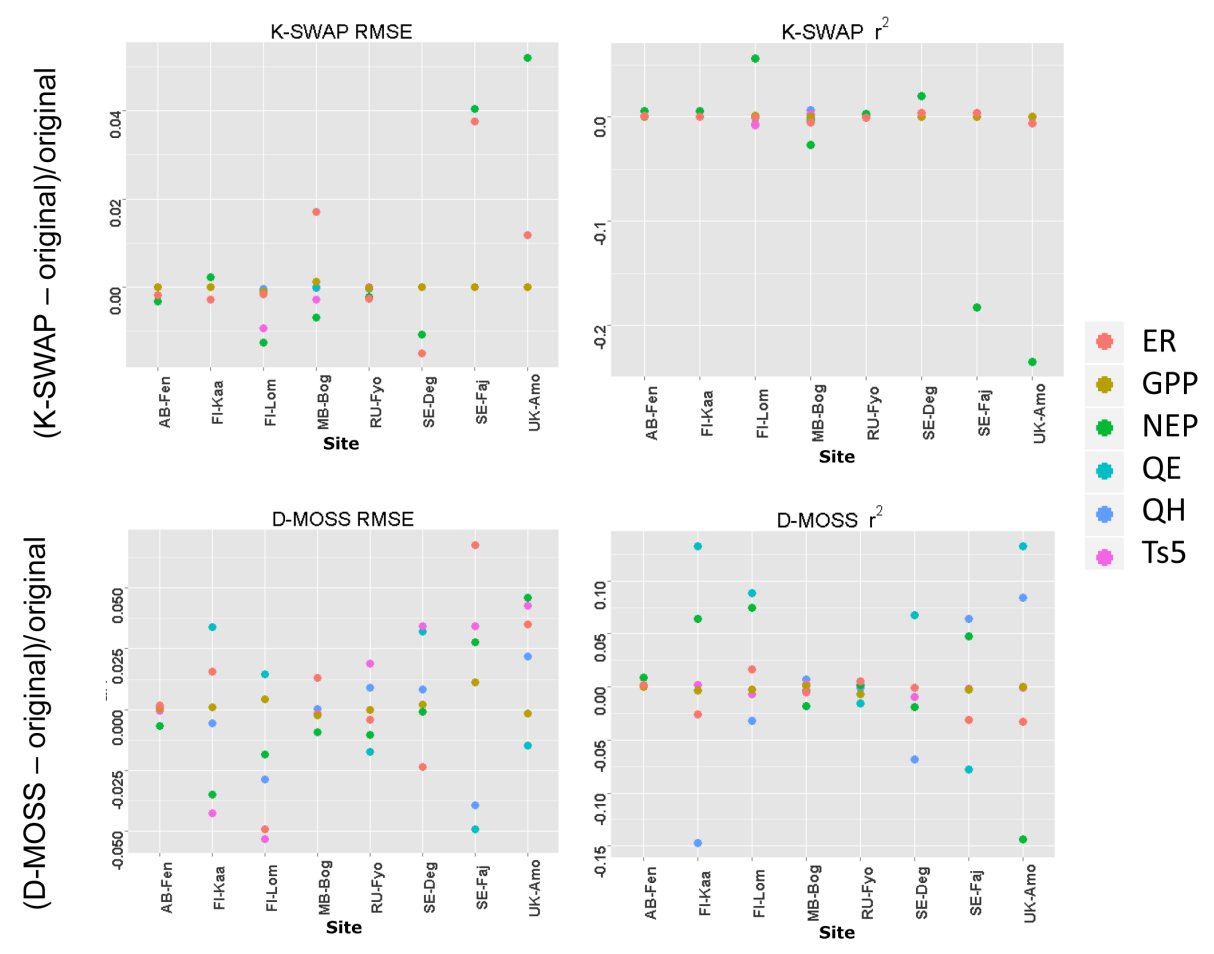

Figure 18. Comparisons of RMSE and $r^{2}$ of the simulated latent heat flux (QE), sensible heat flux (QH), soil temperature at $5 \mathrm{~cm}$ depth $\left(T_{\mathrm{S} 5}\right), \mathrm{GPP}, \mathrm{ER}$, and NEP against the original simulations for the two tests described in Sect. 4.5.

bon balance as shown by the cumulative NEP in Fig. 19, it is evident that the depth of the living moss has more of an effect on the simulation than the decomposition parameters. The difference is largest for FI-Kaa at $29 \%$, and then SE-Faj and SE-Deg at $23 \%$. However, the effect of the moss depth seems to be more site specific than related to the differences between bogs and fens.

Since as noted in Sect. 2.5 above, there was some uncertainty about what value to assign to the anoxic respiration scaling factor $f_{\text {anoxic }}$, a third test was performed to assess the sensitivity of the simulation to this parameter. Frolking et al. (2010) assigned it a value of 0.001, and Frolking et al. (2001) set it to 0.025 for bogs and 0.1 for fens. For our simulations, based on the results of calibration runs we chose a constant value of 0.025 for all of the sites. Since according to Frolking et al. (2001) this value is more representative of bogs, we ran tests for the four fen sites with $f_{\text {anoxic }}$ set first to 0.1 and then to 0.001 . The effect of the changes on the cumulative ER is shown in Fig. 20. It can be seen that the maximum cumulative difference is only about $9 \%$ (for $f_{\text {anoxic }}=0.1$ at SE-Deg), and in the other cases the differences are much smaller. This suggests that we are not incurring any serious errors by using a single value for $f_{\text {anoxic }}$.

Based on the results of the three tests described above, we conclude that when our model is applied at climate time and space scales, as a first-order approximation it will not be necessary to distinguish between fens and bogs through the use of different model parameterizations and coefficients. It will only be necessary to map the locations of peatlands, and whether a given peatland behaves like a bog or a fen will evolve out of the climate forcings, which will determine the vegetation cover and the hydrological characteristics of the peatland in question. This will considerably simplify the global implementation of the model, since global data sets mapping the locations of fens vs. bogs are not available.

\section{Conclusions}

We have presented here an extension of the CLASS-CTEM model, enabling it to simulate the water, energy, and $\mathrm{C}$ cycles of peatlands. The model simulations of the daily $\mathrm{C}$ fluxes are of comparable accuracy to those performed by other models that were developed for a particular site or an area, for example the Finland regional peatland model (Gong et al., 2013) for the FI-Lom site and the MWM for the MB-Bog and SE-Deg sites (Wu et al., 2013). Compared with models that simulate global peatland $\mathrm{C}$ fluxes such as LPJ-WHy (Wania et al., 2009a, b) and CLIMBER2-LPJ (Kleinen et al., 2012), our model performs well and covers the ranges in the observations (Yu et al., 2010). The variations in climatic conditions and in the $\mathrm{C}$ stocks contained by peatlands in nature are difficult to capture completely by the general peatland model here. The model errors were larger for sites with unusual soil properties or vegetation cover. Long-term decline 

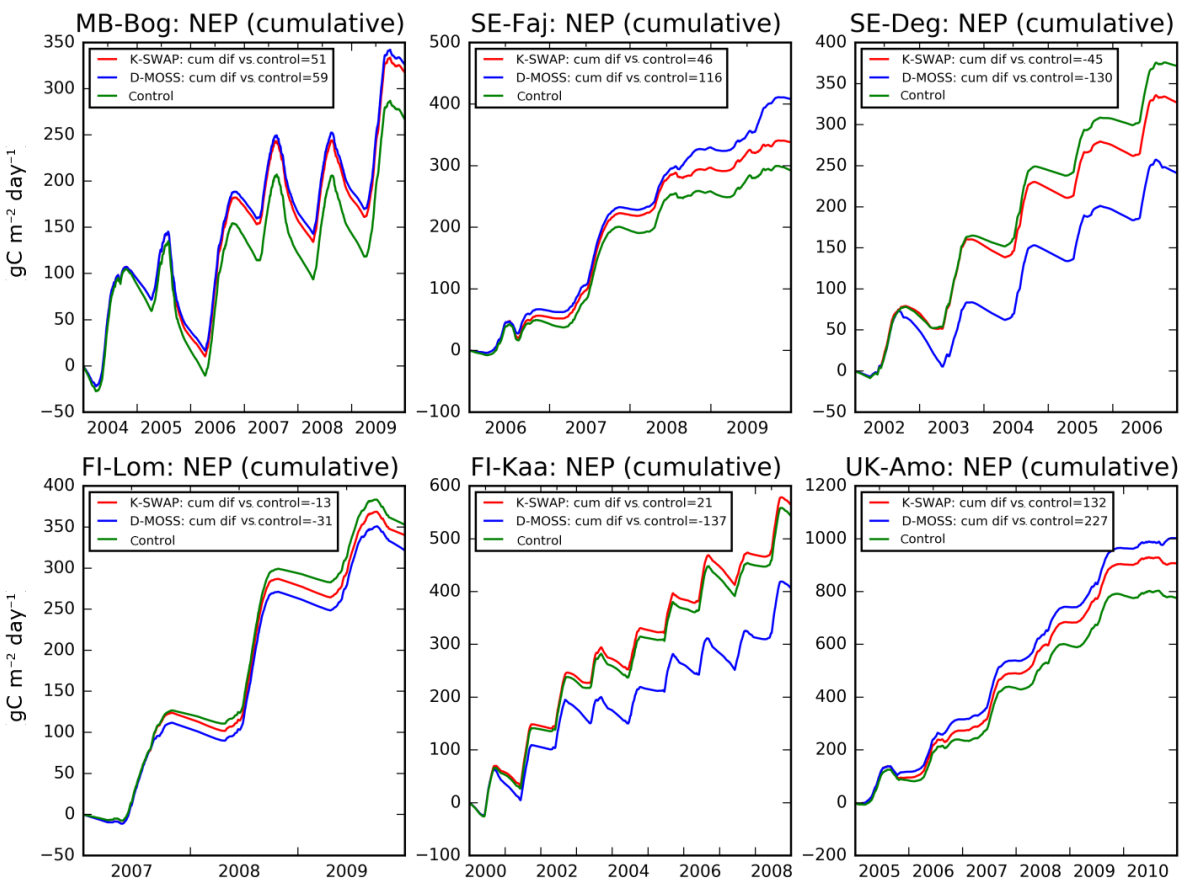

Figure 19. Cumulative NEP for bog and fen sites over the test periods, for the control runs and the two sensitivity tests K-SWAP and D-MOSS.
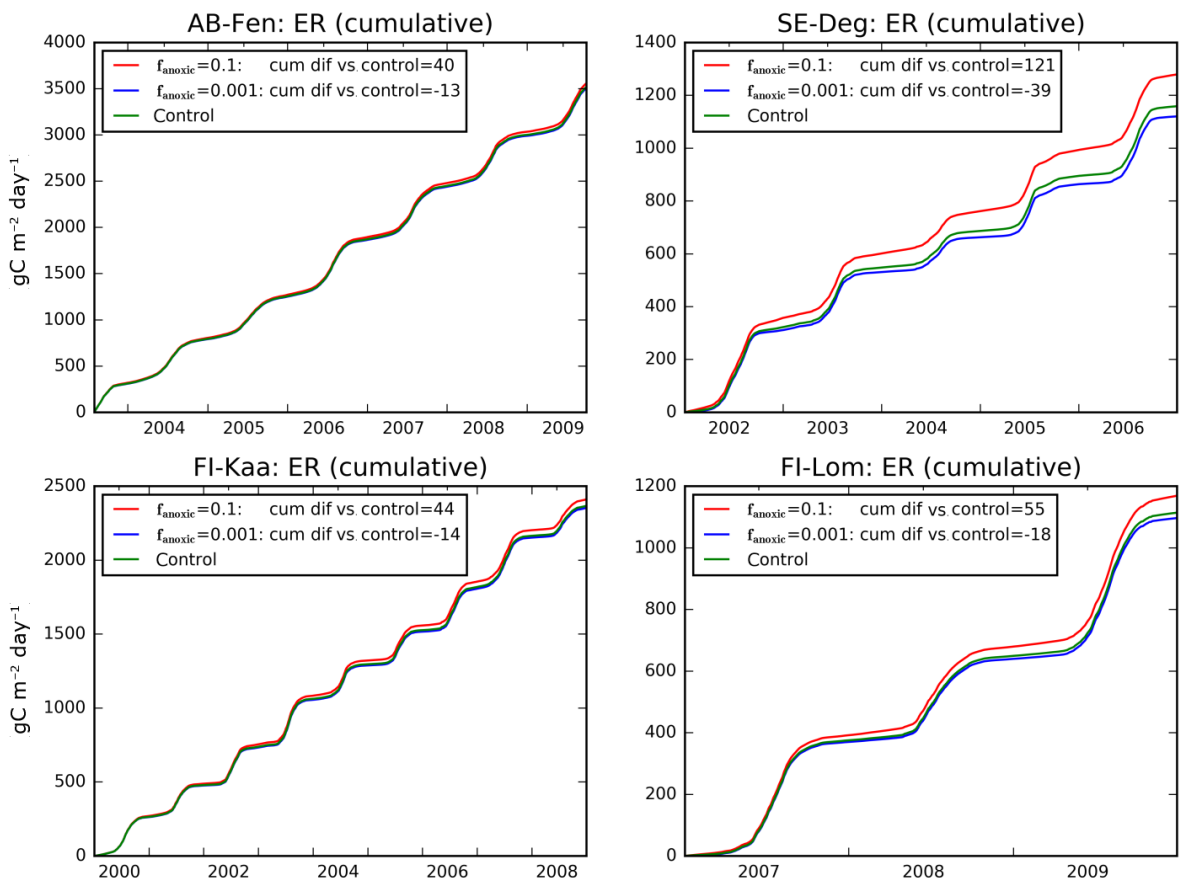

Figure 20. Effect of varying $f_{\text {anoxic }}$ on the ER flux for the four fen sites. The control run was with $f_{\text {anoxic }}$ set to 0.025 .

of water table depth can also shift the vegetation in peatlands from mosses and grasses to shrubs and trees (Flanagan and Syed, 2011; Munir et al., 2014; Talbot et al., 2010). Taking into account such effects could improve the performance of the model (Sulman et al., 2012). Also, other forms of C be- sides $\mathrm{CO}_{2}$, such as methane $\left(\mathrm{CH}_{4}\right)$ and dissolved organic $\mathrm{C}$, are as yet missing from the $\mathrm{C}$ budget in the model and need to be included in order to fully simulate the net $\mathrm{C}$ budget of peatland ecosystems. At the moment, approaches to modelling $\mathrm{CH}_{4}$ emissions from peatlands or wetlands diverge 
widely and further work is needed in areas such as more accurate land surface classification, more realistic emissions from non-inundated wetlands (where water table depth regulates the emissions) and peat soils from high latitudes (Bohn et al., 2015). This study has tested the model's performance on northern peatlands only; further tests are needed to validate the model on the remaining $10 \%$ of peatlands (Yu, 2011) that are located in the tropical region and Southern Hemisphere.

The coupled CLASS-CTEM model serves as the land surface component for the family of Canadian Earth system models (CanESMs). Despite some limitations in simulating unusual peatlands, the extended version that we have presented here shows an overall good skill in simulating the water and energy dynamics and the daily and annual $\mathrm{C}$ fluxes in peatlands. Contrary to models designed for specific sites such as the MWM, the peatland model presented here does not need to distinguish between bogs and fens, which constitutes a distinct advantage for application in an ESM at the global scale.

\section{Code availability}

Fortran code for the CLASS-CTEM modelling framework is available on request and upon agreeing to Environment Canada's licensing agreement available at http://collaboration.cmc.ec.gc.ca/science/rpn.comm/ license.html. Please contact the third author, Joe Melton (joe.melton@canada.ca), to obtain model code.

Acknowledgements. Y. Wu was supported by a Natural Sciences and Engineering Research Council of Canada (NSERC) Postdoctoral Visiting Fellowship. We are grateful to Nigel Roulet for valuable and inspiring advice on the model design and for sharing with us the code of the McGill Wetland Model. We acknowledge Jianghua $\mathrm{Wu}$ and Mats Nilsson for providing the original data for the Mer Bleue bog and the Degerö Stormyr. We thank Vivek Arora for insightful comments on the model design and on the manuscript. We also thank Paul Bartlett and Ed Chan for fruitful discussions and technical assistance. Finally, we thank Nigel Roulet and an anonymous reviewer for helpful and thoughtful comments, which have much improved the paper.

Edited by: J. Kala

Reviewed by: N. Roulet and one anonymous referee

\section{References}

Adkinson, A. C. and Humphreys, E. R.: The response of carbon dioxide exchange to manipulations of Sphagnum water content in an ombrotrophic bog, Ecohydrology, 4.6, 733-743, 2011.

Adkinson, A. C., Syed, K. H., and Flanagan, L. B.: Contrasting responses of growing season ecosystem $\mathrm{CO}_{2}$ exchange to variation in temperature and water table depth in two peatlands in northern Alberta, Canada, J. Geophys. Res.-Biogeo., 116, G01004, doi:10.1029/2010JG001512, 2011.

Ångström, A.: A study of the radiation of the atmosphere, Smithson. Misc. Collect., 65, 1-159, 1918.

Arora, V. K.: Simulating energy and carbon fluxes over winter wheat using coupled land surface and terrestrial ecosystem models, Agr. Forest Meteorol., 118, 21-47, 2003.

Arora, V. K. and Boer, G. J.: A parameterization of leaf phenology for the terrestrial ecosystem component of climate models, Glob. Change Biol., 11, 39-59, doi:10.1111/j.13652486.2004.00890.x, 2005.

Aurela, M., Tuovinen, J.-P., and Laurila, T.: Carbon dioxide exchange in a subarctic peatland ecosystem in northern Europe measured by the eddy covariance technique, J. Geophys. Res.Atmos., 103, 11289-11301, 1998.

Aurela, M., Lohila, A., Tuovinen, J.-P., Hatakka, J., Riutta, T., and Laurila, T.: Carbon dioxide exchange on a northern boreal fen, Boreal Environ. Res., 14, 699-710, 2009.

Bazile, E., Traullé, O., Barral, H., Vihma, T., Holtslag, A. A. M., and Svensson, G.: GABLS4: An intercomparison case for 1D models to study the stable boundary layer at Dome-C on the Antarctic plateau, EMS Annual Meeting Abstracts, Vol. 10, EMS2013578, 2013.

Ballantyne, A. P., Alden, C. B., Miller, J. B., Tans, P. P., and White, J. W. C.: Increase in observed net carbon dioxide uptake by land and oceans during the past 50 years, Nature, 488, 70-72, 2012.

Bellisario, L. M., Dale Boudreau, L., Verseghy, D. L., Rouse, W. R., and Blanken, P. D.: Comparing the performance of the Canadian land surface scheme@ class) for two subarctic terrain types, Atmosphere-Ocean, 38, 181-204, 2000.

Beringer, J., Lynch, A. H., Chapin III, F. S., Mack, M., and Bonan, G. B.: The representation of arctic soils in the land surface model: the importance of mosses, J. Climate, 14, 3324-3335, 2001.

Bohn, T. J., Melton, J. R., Ito, A., Kleinen, T., Spahni, R., Stocker, B. D., Zhang, B., Zhu, X., Schroeder, R., Glagolev, M. V., Maksyutov, S., Brovkin, V., Chen, G., Denisov, S. N., Eliseev, A. V., Gallego-Sala, A., McDonald, K. C., Rawlins, M. A., Riley, W. J., Subin, Z. M., Tian, H., Zhuang, Q., and Kaplan, J. O.: WETCHIMP-WSL: intercomparison of wetland methane emissions models over West Siberia, Biogeosciences, 12, 3321-3349, doi:10.5194/bg-12-3321-2015, 2015.

Bonan, G. B., Levis, S., Kergoat, L., and Oleson, K. W.: Landscapes as patches of plant functional types: An integrating concept for climate and ecosystem models, Global Biogeochem. Cy., 16, 5$1,2002$.

Bond-Lamberty, B., Gower, S. T., and Ahl, D. E.: Improved simulation of poorly drained forests using Biome-BGC, Tree Physiol., 27, 703-715, 2007.

Bubier, J. L., Moore, T. R., and Crosby, G.: Fine-scale vegetation distribution in a cool temperate peatland, Botany, 84, 910-923, 2006. 
Camill, P. and Clark, J. S.: Long-term perspectives on lagged ecosystem responses to climate change: permafrost in boreal peatlands and the grassland/woodland boundary, Ecosystems, 3, 534-544, 2000.

Canada Committee on Ecological (Biophysical) Land Classification: National Wetlands Working Group. The Canadian wetland classification system, edited by: Warner, B. G. and Rubec, C. D. A., Wetlands Research Branch, University of Waterloo, 1997.

Christensen, J. H., Krishna Kumar, K., Aldrian, E., An, S.-I., Cavalcanti, I. F. A., de Castro, M., Dong, W., Goswami, P., Hall, A., Kanyanga, J. K., Kitoh, A., Kossin, J., Lau, N.-C., Renwick, J., Stephenson, D. B., Xie, S.-P., and Zhou, T.: Climate Phenomena and their Relevance for Future Regional Climate Change, in: Climate Change 2013: The Physical Science Basis. Contribution of Working Group I to the Fifth Assessment Report of the Intergovernmental Panel on Climate Change, edited by: Stocker, T. F., Qin, D., Plattner, G.-K., Tignor, M., Allen, S. K., Boschung, J., Nauels, A., Xia, Y., Bex, V., and Midgley, P. M., Cambridge University Press, Cambridge, United Kingdom and New York, NY, USA, 2013.

Comer, N. T., Lafleur, P. M., Roulet, N. T., Letts, M. G., Skarupa, M., and Verseghy, D.: A test of the Canadian Land Surface Scheme (CLASS) for a variety of wetland types, Atmos.-Ocean, 38, 161-179, 2000.

Crawford, T. M. and Duchon, C. E.: An improved parameterization for estimating effective atmospheric emissivity for use in calculating daytime downwelling longwave radiation, J. Appl. Meteorol., 38, 474-480, 1999.

Davidson, E. A. and Janssens, I. A.: Temperature sensitivity of soil carbon decomposition and feedbacks to climate change, Nature, 440, 165-173, 2006.

Dorrepaal, E., Toet, S., van Logtestijn, R. S. P., Swart, E., van de Weg, M. J., Callaghan, T. V., and Aerts, R.: Carbon respiration from subsurface peat accelerated by climate warming in the subarctic, Nature, 460, 616-619, 2009.

Dimitrov, D. D., Grant, R. F., Lafleur, P. M., and Humphreys, E. R.: Modeling the effects of hydrology on ecosystem respiration at Mer Bleue bog, J. Geophys. Res., 115, G04043, doi:10.1029/2010JG001312, 2010.

Dinsmore, K. J., Billett, M. F., Skiba, U. M., Rees, R. M., Drewer, J., and Helfter, C.: Role of the aquatic pathway in the carbon and greenhouse gas budgets of a peatland catchment, Glob. Change Biol., 16, 2750-2762, 2010.

Drewer, J., Lohila, A., Aurela, M., Laurila, T., Minkkinen, K., Penttilä, T., Dinsmore, K. J., McKenzie, R. M., Helfter, C., Flechard, C., Sutton, M. A., and Skiba, U. M.: Comparison of greenhouse gas fluxes and nitrogen budgets from an ombotrophic bog in Scotland and a minerotrophic sedge fen in Finland, Eur. J. Soil Sci., 61, 640-650, 2010.

Ekici, A., Beer, C., Hagemann, S., Boike, J., Langer, M., and Hauck, C.: Simulating high-latitude permafrost regions by the JSBACH terrestrial ecosystem model, Geosci. Model Dev., 7, 631-647, doi:10.5194/gmd-7-631-2014, 2014.

Farquhar, G. D.: Models of Integrated Photosynthesis of Cells and Leaves, Philos. Trans. R. Soc. Lond. B Biol. Sci., 323, 357-367, 1989.

Flanagan, L. B. and Syed, K. H.: Stimulation of both photosynthesis and respiration in response to warmer and drier conditions in a boreal peatland ecosystem, Glob. Change Biol., 17, 2271-2287, 2011.

Frolking, S., Goulden, M. L., Wofsy, S. C., Fan, S.-M., Sutton, D. J., Munger, J. W., Bazzaz, A. M., Daube, B. C., Crill, P. M., Aber, J. D., Band, L. E., Wang, X., Savage, K., Moore, T. and Harriss, R. C.: Modelling temporal variability in the carbon balance of a spruce/moss boreal forest, Glob. Change Biol., 2, 343-366, 1996.

Frolking, S., Roulet, N. T., Moore, T. R., Richard, P. J. H., Lavoie, M., Muller, S. D.: Modeling northern peatland decomposition and peat accumulation, Ecosystems, 4, 479-498, 2001.

Frolking, S., Roulet, N. T., Tuittila, E., Bubier, J. L., Quillet, A., Talbot, J., and Richard, P. J. H.: A new model of Holocene peatland net primary production, decomposition, water balance, and peat accumulation, Earth Syst. Dynam., 1, 1-21, doi:10.5194/esd-11-2010, 2010.

Givnish, T. J.: Adaptive significance of evergreen vs. deciduous leaves: solving the triple paradox, Silva Fennica, 36, 703-743, 2002.

Gong, J., Kellomäki, S., Wang, K., Zhang, C., Shurpali, N., and Martikainen, P. J.: Modeling $\mathrm{CO}_{2}$ and $\mathrm{CH}_{4}$ flux changes in pristine peatlands of Finland under changing climate conditions, Ecol. Modell., 263, 64-80, 2013.

Granberg, G., Grip, H., Ottosson Löfvenius, M., Sundh, I., Svensson, B. H., and Nilsson, M.: A simple model for simulation of water content, soil frost, and soil temperatures in boreal mixed mires, Water Resour. Res., 35, 3771-3782, 1999.

Hayward, P. M. and Clymo, R. S.: Profiles of water content and pore size in Sphagnum and peat, and their relation to peat bog ecology, P. Roy. Soc. Lond. B Bio., 215, 299-325, 1982.

Kaplan, J. O., Bigelow, N. H., Prentice, I. C., Harrison, S. P., Bartlein, P. J., Christensen, T. R., Cramer, W., Matveyeva, N. V., McGuire, A. D., Murray, D. F., Razzhivin, V. Y., Smith, B., Walker, D. A., Anderson, P. M., Andreev, A. A., Brubaker, L. B., Edwards, M. E., and Lozhkin, A. V.: Climate change and Arctic ecosystems: 2. Modeling, paleodata-model comparisons, and future projections, J. Geophys. Res.-Atmos., 108, 8171, doi:10.1029/2002JD002559, 2003.

Kleinen, T., Brovkin, V., and Schuldt, R. J.: A dynamic model of wetland extent and peat accumulation: results for the Holocene, Biogeosciences, 9, 235-248, doi:10.5194/bg-9-235-2012, 2012.

Kottek, M., Grieser, J., Beck, C., Rudolf, B., and Rubel, F.: World Map of the Köppen-Geiger climate classification updated, Meteorol. Z., 15, 259-263, doi:10.1127/0941-2948/2006/0130, 2006.

Laine, A. M., Bubier, J., Riutta, T., Nilsson, M. B., Moore, T. R., Vasander, H., and Tuittila, E.-S.: Abundance and composition of plant biomass as potential controls for mire net ecosytem $\mathrm{CO}_{2}$ exchange, Botany, 90, 63-74, 2011.

Lee, T. J. and Pielke, R. A.: Estimating the soil surface specific humidity, J. Appl. Meteorol., 31, 480-484, 1992.

Leith, F. I., Garnett, M. H., Dinsmore, K. J., Billett, M. F., and Heal, K. V.: Source and age of dissolved and gaseous carbon in a peatland-riparian-stream continuum: a dual isotope $\left({ }^{14} \mathrm{C}\right.$ and $\left.\delta^{13} \mathrm{C}\right)$ analysis, Biogeochemistry, 119, 415-433, 2014.

Letts, M. J., Roulet, N. T., Comer, N. T., Skarupa, M. R., and Verseghy, D. L.: Parametrization of peatland hydraulic properties for the Canadian Land Surface Scheme, Atmos.-Ocean, 38, 141-160, 2000.

Loisel, J. and Garneau, M.: Late Holocene paleoecohydrology and carbon accumulation estimates from two boreal peat bogs in east- 
ern Canada: Potential and limits of multi-proxy archives, Palaeogeogr. Palaeocl., 291, 493-533, 2010.

Ise, T., Dunn, A. L., Wofsy, S. C., and Moorcroft, P. R.: High sensitivity of peat decomposition to climate change through watertable feedback, Nat. Geosci., 1, 763-766, 2008.

Lafleur, P. M., Hember, R. A., Admiral, S. W., and Roulet, N. T.: Annual and seasonal variability in evapotranspiration and water table at a shrub-covered bog in southern Ontario, Canada, Hydrol. Process., 19, 3533-3550, 2005.

Lund, M., Lindroth, A., Christensen, T. R., and Ström, L.: Annual $\mathrm{CO}_{2}$ balance of a temperate bog, Tellus B, 59, 804-811, 2007.

Maanavilja, L., Riutta, T., Aurela, M., Pulkkinen, M., Laurila, T., and Tuittila, E.-S.: Spatial variation in $\mathrm{CO}_{2}$ exchange at a northern aapa mire, Biogeochemistry, 104, 325-345, 2011.

McCarter, C. P. R. and Price, J. S.: Ecohydrology of Sphagnum moss hummocks: mechanisms of capitula water supply and simulated effects of evaporation, Ecohydrol., 7, 33-44, doi:10.1002/eco.1313, 2012.

McCree, K. J.: Test of current definitions of photosynthetically active radiation against leaf photosynthesis data, Agr. Meteorol., 10, 443-453, 1972.

McGuire, A. D., Anderson, L. G., Christensen, T. R., Dallimore, S., Guo, L., Hayes, D. J., Heimann, M., Lorenson, T. D., Macdonald, R. W. and Roulet, N.: Sensitivity of the carbon cycle in the Arctic to climate change, Ecol. Monogr., 79, 523-555, 2009.

Melton, J. R. and Arora, V. K.: Sub-grid scale representation of vegetation in global land surface schemes: implications for estimation of the terrestrial carbon sink, Biogeosciences., 11, 10211036, doi:10.5194/bg-11-1021-2014, 2014.

Melton, J. R. and Arora, V. K.: Competition between plant functional types in the Canadian Terrestrial Ecosystem Model (CTEM) v. 2.0, Geosci. Model Dev., 9, 323-361, doi:10.5194/gmd-9-323-2016, 2016.

Melton, J. R., Shrestha, R. K., and Arora, V. K.: The influence of soils on heterotrophic respiration exerts a strong control on net ecosystem productivity in seasonally dry Amazonian forests, Biogeosciences, 12, 1151-1168, doi:10.5194/bg-12-1151-2015, 2015.

Moore, T. R., Bubier, J. L., Frolking, S. E., Lafleur, P. M., and Roulet, N. T.: Plant biomass and production and $\mathrm{CO}_{2}$ exchange in an ombrotrophic bog, J. Ecol., 90, 25-36, 2002.

Moore, T. R., Lafleur, P. M., Poon, D. M., Heumann, B. W., Seaquist, J. W., and Roulet, N. T.: Spring photosynthesis in a cool temperate bog, Glob. Change Biol., 12, 2323-2335, 2006.

Munir, T. M., Xu, B., Perkins, M., and Strack, M.: Responses of carbon dioxide flux and plant biomass to water table drawdown in a treed peatland in northern Alberta: a climate change perspective, Biogeosciences, 11, 807-820, doi:10.5194/bg-11-8072014, 2014.

Murphy, M. T., McKinley, A., and Moore, T. R.: Variations in above-and below-ground vascular plant biomass and water table on a temperate ombrotrophic peatland, Botany, 87, 845-853, 2009.

O'Donnell, J. A., Romanovsky, V. E., Harden, J. W., and McGuire, A. D.: The effect of moisture content on the thermal conductivity of moss and organic soil horizons from black spruce ecosystems in interior Alaska, Soil Sci., 174, 646-651, 2009.

Peichl, M., Öquist, M., Ottosson Löfvenius, M., Ilstedt, U., Sagerfors, J., Grelle, A., Lindroth, A., and Nilsson, M. B.: A 12-year record reveals pre-growing season temperature and water table level threshold effects on the net carbon dioxide exchange in a boreal fen, Environ. Res. Lett., 9, 055006, doi:10.1088/17489326/9/5/055006, 2014.

Porada, P., Weber, B., Elbert, W., Pöschl, U., and Kleidon, A.: Estimating global carbon uptake by lichens and bryophytes with a process-based model, Biogeosciences, 10, 6989-7033, doi:10.5194/bg-10-6989-2013, 2013.

Price, J. S. and Whittington, P. N.: Water flow in Sphagnum hummocks: Mesocosm measurements and modelling, J. Hydrol., 381, 333-340, 2010.

Price, J. S., Whittington, P. N., Elrick, D. E., Strack, M., Brunet, N., and Faux, E.: A method to determine unsaturated hydraulic conductivity in living and undecomposed moss, Soil Sci. Soc. Am. J., 72, 487-491, 2008.

R Core Team: R: A language and environment for statistical computing, R Foundation for Statistical Computing, Vienna, Austria, available at: http://www.R-project.org/ (last access: 22 October 2015.), 2014.

Reich, P. B., Ellsworth, D. S., and Walters, M. B.: Leaf structure (specific leaf area) modulates photosynthesis-nitrogen relations: evidence from within and across species and functional groups, Funct. Ecol., 12, 948-958, 1998.

Rice, S. K., Aclander, L., and Hanson, D. T.: Do bryophyte shoot systems function like vascular plant leaves or canopies? Functional trait relationships in Sphagnum mosses (Sphagnaceae), Am. J. Bot., 95, 1366-1374, 2008.

Robroek, B. J. M., Schouten, M. G. C., Limpens, J., Berendse, F., and Poorter, H.: Interactive effects of water table and precipitation on net $\mathrm{CO}_{2}$ assimilation of three co-occurring Sphagnum mosses differing in distribution above the water table, Glob. Change Biol., 15, 680-691, 2009.

Roulet, N. T., Lafleur, P. M., Richard, P. J., Moore, T. R., Humphreys, E. R., and Bubier, J. I. L. L.: Contemporary carbon balance and late Holocene carbon accumulation in a northern peatland, Glob. Change Biol., 13, 397-411, 2007.

Rydin, H. and Jeglum, J.: The Biology of Peatlands, Oxford Univ. Press, Oxford, United Kingdom, 2006.

Sagerfors, J., Lindroth, A., Grelle, A., Klemedtsson, L., Weslien, P., and Nilsson, M.: Annual $\mathrm{CO}_{2}$ exchange between a nutrientpoor, minerotrophic, boreal mire and the atmosphere, J. Geophys. Res.-Biogeo., 113, G01001, doi:10.1029/2006JG000306, 2008.

Schuldt, R. J., Brovkin, V., Kleinen, T., and Winderlich, J.: Modelling Holocene carbon accumulation and methane emissions of boreal wetlands - an Earth system model approach, Biogeosciences, 10, 1659-1674, doi:10.5194/bg-10-1659-2013, 2013.

Seneviratne, S. I., Corti, T., Davin, E. L., Hirschi, M., Jaeger, E. B., Lehner, I., Orlowsky, B., and Teuling, A. J.: Investigating soil moisture-climate interactions in a changing climate: A review, Earth-Sci. Rev., 99, 125-161, 2010.

Spahni, R., Joos, F., Stocker, B. D., Steinacher, M., and Yu, Z. C.: Transient simulations of the carbon and nitrogen dynamics in northern peatlands: from the Last Glacial Maximum to the 21st century, Clim. Past, 9, 1287-1308, doi:10.5194/cp-9-1287-2013, 2013.

St-Hilaire, F., Wu, J., Roulet, N. T., Frolking, S., Lafleur, P. M., Humphreys, E. R., and Arora, V.: McGill wetland model: evaluation of a peatland carbon simulator developed for global assess- 
ments, Biogeosciences, 7, 3517-3530, doi:10.5194/bg-7-35172010, 2010.

Sulman, B., Desai, A., and Schroeder, N.: Impact of hydrological variations on modeling of peatland $\mathrm{CO}_{2}$ fluxes: Results from the North American Carbon Program site synthesis, J. Geophys. Res., 117, G01031, doi:10.1029/2011JG001862, 2012.

Syed, K. H., Flanagan, L. B., Carlson, P. J., Glenn, A. J., and Van Gaalen, K. E.: Environmental control of net ecosystem $\mathrm{CO}_{2}$ exchange in a treed, moderately rich fen in northern Alberta, Agr. Forest Meteorol., 140, 97-114, 2006.

Talbot, J., Richard, P. J. H., Roulet, N. T., and Booth, R. K.: Assessing long-term hydrological and ecological responses to drainage in a raised bog using paleoecology and a hydrosequence, J. Veg. Sci., 21, 143-156, 2010.

Tanja, S., Berninger, F., Vesala, T., Markkanen, T., Hari, P., Mäkelä, A., Ilvesniemi, H., Hanninen, H., Nikinmaa, E., Huttula, T., Laurila, T., Aurela, M, Grelle, A., Lindroth, A., Arneth, A., Shibistova, O., and Lloyd, J.: Air temperature triggers the recovery of evergreen boreal forest photosynthesis in spring, Glob. Change Biol., 9, 1410-1426, 2003.

Tarnocai, C.: The effect of climate change on carbon in Canadian peatlands, Glob. Planet. Change, 53, 222-232, 2006.

Taylor, K. E.: Summarizing multiple aspects of model performance in a single diagram, J. Geophys. Res., 106, 7183-7192, doi:10.1029/2000JD900719, 2001.

Todd-Brown, K. E. O., Randerson, J. T., Post, W. M., Hoffman, F. M., Tarnocai, C., Schuur, E. A. G., and Allison, S. D.: Causes of variation in soil carbon simulations from CMIP5 Earth system models and comparison with observations, Biogeosciences, 10, 1717-1736, doi:10.5194/bg-10-1717-2013, 2013.

Todd-Brown, K. E. O., Randerson, J. T., Hopkins, F., Arora, V., Hajima, T., Jones, C., Shevliakova, E., Tjiputra, J., Volodin, E., Wu, T., Zhang, Q., and Allison, S. D.: Changes in soil organic carbon storage predicted by Earth system models during the 21st century, Biogeosciences, 11, 2341-2356, doi:10.5194/bg-11-23412014, 2014.

Turetsky, M. R.: The role of bryophytes in carbon and nitrogen cycling, The Bryologist, 106, 395-409, 2003.

Turetsky, M. R., Bond-Lamberty, B., Euskirchen, E., Talbot, J., Frolking, S., McGuire, A. D., and Tuittila, E.-S.: The resilience and functional role of moss in boreal and arctic ecosystems, New Phytol., 196, 49-67, doi:10.1111/j.14698137.2012.04254.x, 2012.

Turetsky, M. R., Kotowska, A., Bubier, J., Dise, N. B., Crill, P., Hornibrook, E. R. C., Minkkinen, K., Moore, T. R., MyersSmith, I. H., Nykänen, H., Olefeldt, D., Rinne, J., Saarnio, S., Shurpali, N., Tuittila, E.-S., Waddington, J. M., White, J. R., Wickland, K. P., and Wilmking, M.: A synthesis of methane emissions from 71 northern, temperate, and subtropical wetlands, Glob. Chane Biol., 20, 2183-2197, 2014.

Verseghy, D.: CLASS - the Canadian Land Surface Scheme (Version 3.6), Technical Documentation, Tech. rep., Science and Technology Branch, Environment Canada, 2012.

Verseghy, D. L.: CLASS - a Canadian land surface scheme for GCMs, I. Soil model, Int. J. Climatol., 11, 111-133, 1991.

Verseghy, D. L., McFarlane, N. A., and Lazare, M.: CLASS - a Canadian land surface scheme for GCMs, II. Vegetation model and coupled runs, Int. J. Climatol., 13, 347-370, 1993.
Vitt, D. H.: A key and review of bryophytes common in North American peatlands, Evansia, 31, 121-158, 2014.

Ward, S. E., Ostle, N. J., Oakley, S., Quirk, H., Henrys, P. A., and Bardgett, R. D.: Warming effects on greenhouse gas fluxes in peatlands are modulated by vegetation composition, Ecol. Lett., 16, 1285-1293, 2013.

Wang, H., Richardson, C. J., and Ho, M.: Dual controls on carbon loss during drought in peatlands, Nature Climate Change, 5, 584587, 2015.

Wania, R., Ross, I., and Prentice,: Integrating peatlands and permafrost into a dynamic global vegetation model: 1. Evaluation and sensitivity of physical land surface processes, Global Biogeochem. Cy., 23, GB3014, doi:10.1029/2008GB003412, 2009a.

Wania, R., Ross, I., and Prentice, I. C.: Integrating peatlands and permafrost into a dynamic global vegetation model: 2. Evaluation and sensitivity of vegetation and carbon cycle processes, Global Biogeochem. Cy., 23, GB3015, doi:10.1029/2008GB003413, 2009b.

Williams, T. G. and Flanagan, L. B.: Measuring and modelling environmental influences on photosynthetic gas exchange in Sphagnum and Pleurozium, Plant Cell Environ., 21, 555-564, 1998.

$\mathrm{Wu}, \mathrm{J}$. and Roulet, N. T.: Climate change reduces the capacity of northern peatlands to absorb the atmospheric carbon dioxide: The different responses of bogs and fens, Global Biogeochem. Cy., 28, 1005-1024, 2014.

Wu, J., Roulet, N. T., Sagerfors, J., and Nilsson, M. B.: Simulation of six years of carbon fluxes for a sedge-dominated oligotrophic minerogenic peatland in Northern Sweden using the McGill Wetland Model (MWM), J. Geophys. Res.-Biogeo., 118, 795-807, 2013.

Wu, Y. and Blodau, C.: PEATBOG: a biogeochemical model for analyzing coupled carbon and nitrogen dynamics in northern peatlands, Geosci. Model Dev., 6, 1173-1207, doi:10.5194/gmd-61173-2013, 2013.

Yebra, M., Van Dijk, A. I., Leuning, R., and Guerschman, J. P.: Global vegetation gross primary production estimation using satellite-derived light-use efficiency and canopy conductance, Remote Sens. Environ., 163, 206-216, 2015.

$\mathrm{Yu}, \mathrm{Z}$ : : Holocene carbon flux histories of the world's peatlands Global carbon-cycle implications, Holocene, 21, 761-774, 2011.

Yu, Z., Loisel, J., Brosseau, D. P., Beilman, D. W., and Hunt, S.J.: Global peatland dynamics since the Last Glacial Maximum, Geophys. Res. Lett., 37, L13402, doi:10.1029/2010GL043584, 2010.

Yu, Z., Loisel, J., Turetsky, M. R., Cai, S., Zhao, Y., Frolking, S., MacDonald, G. M., and Bubier, J. L.: Evidence for elevated emissions from high-latitude wetlands contributing to high atmospheric $\mathrm{CH}_{4}$ concentration in the early Holocene, Global Biogeochem. Cy., 27, 131-140, 2013.

Yurova, A., Wolf, A., Sagerfors, J., and Nilsson, M.: Variations in net ecosystem exchange of carbon dioxide in a boreal mire: Modeling mechanisms linked to water table position, J. Geophys. Res.-Biogeo., 112, G02025, doi:10.1029/2006JG000342, 2007. 